\title{
Ultimate Strength and Fracture Sequence of Bolted Connections to Thin-Walled Carbon Steel
}

\author{
Mohammed Mahmood ${ }^{1}$, Ahmed Elamin ${ }^{2}$ and Walid Tizani ${ }^{3}$ \\ ${ }^{1}$ Department of Civil Engineering, University of Diyala, Iraq \\ ${ }^{2}$ Department of Civil Engineering, The University of Nottingham Ningbo China \\ ${ }^{3}$ Department of Civil Engineering, The University of Nottingham, UK
}

\begin{abstract}
Recent experimental studies on single shear bolted connections to thin-walled carbon steel indicate the need for parametric analysis to understand the behaviour of the connection. In this paper, finite element analysis was performed to investigate the ultimate behaviour and failure sequence of these connections. A parametric analysis was performed to investigate the effect of plate thickness, end distance and curling displacement on the connection behaviour. Five possible modes of failure were identified and analytical models for estimating the connection strength for these modes were proposed. Within the range of the validity of the study, the end distance was the most influential parameter, but the strength improvement becomes negligible at edge distance of $42 \mathrm{~mm}$ for plate thickness less than or equal to $3.5 \mathrm{~mm}$ and $48 \mathrm{~mm}$ for plate thickness greater than $3.5 \mathrm{~mm}$. Therefore, it is recommended to limit the maximum end distance to $50 \mathrm{~mm}$. The curling displacement is found to affect the stress distribution in the plate as it could reduce the connection strength by $12 \%$. It is considered as a sign of failure only when it reaches $0.5 \mathrm{~mm}$ before the ultimate strength of the connection is reached. The proposed models are more accurate in predicting the connection ultimate strength when compared to EC3,
\end{abstract} AISI and AISC predictions.

Keywords: Bolted connections; Thin-walled Carbon steel; Single shear bolt; Fracture sequence.

\section{INTRODUCTION}

For practical reasons, bolted joints are widely used in steel structures. They allow for a quick and easy assembly of structural elements and can transfer bending, shear and axial forces [1]. The construction industry saw an increase in the use of thin-walled (light gauge) steel elements as structural members in recent years. However, reliable connection design information for these sections are not available. Such information, in addition to economical and versatile properties of 
thin-walled steel, can make these elements more attractive over other forms of construction. Early example of research into the area of thin-walled connection is the study of Winter [2], which focused mainly on bolted connections. Kim and Yura in 1999 conducted an experimental study on the effect of end distance on the bearing strength in one and two lap connections. It was reported that a large end distance results in higher deformation at the ultimate strength [3]. Topkaya in 2004 [4] proposed equations for calculating block shear load capacity for steel tension members based on finite element analysis results. Kim and Kuwamura in 2007 [5] performed finite element analysis to investigate the behaviour of thinwalled single shear stainless steel bolted connections. The out of plane displacement in the direction of the plate thickness which occurs at the end of the connection plate (curling) was reported as an influential parameter on the ultimate strength of the connection. A parametric study using finite element was performed by Kim et al. [6] to investigate the ultimate strength and curling behaviour of single shear bolted connections. It was confirmed that the effect of curling should be considered in estimating the connection strength and accordingly a revised design formula was suggested. Teh and Clements [7] performed experimental study to examine the mechanism of block shear failure in bolted connections in G450 steel sheets. The study defined shear lag factor and proposed more accurate rational equation to predict the connection strength. Clements and Teh [8] used finite element analysis to examine the behaviour of bolted connection in steel sheets. The shear failure planes were identified at midway between the gross and the net shear planes and termed as active shear plane. Kim and Lim [9] employed finite element analysis to predict the ultimate strength, fracture mode and curling in austenitic stainless steel single shear bolted connections. It was confirmed that the occurrence of curling displacement reduces the ultimate strength and changes the fracture patterns. An extensive experimental study in addition to finite element analysis were conducted by Kim et al. $[10,11]$ to investigate the fracture mechanism and the curling behaviour in single shear bolted connection in thin-walled carbon steel. The main variables of the tests were the plate thickness and the end distance. Curling was reported to occur in specimens with large end distance, which was a companied by a reduction in the ultimate strength of the connection.

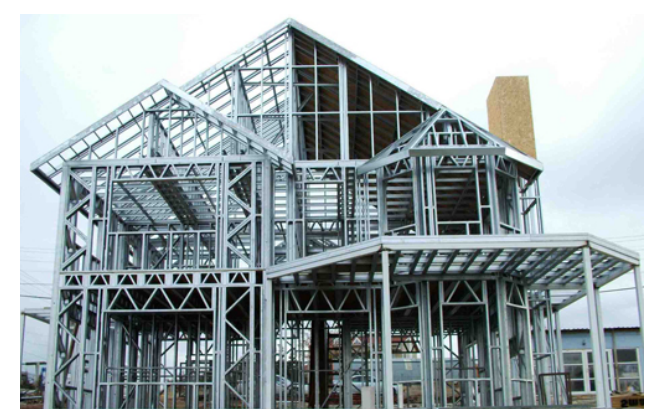

Figure 1: Light steel thin-walled structures [12]

The evidence presented in the literature suggests that the available design equations for thin-walled carbon steel single shear bolted connections are not adequately simulating the failure modes. Therefore, there is a need to device more precise equations that can simulate the real behaviour of the connection and provide reliable estimation to the connection strength. 
Hence, the aim of this research is to investigate the ultimate strength and fracture sequence of single shear bolted connections to thin-walled carbon steel. Parametric finite element analysis were performed to provide adequate information which could be used to devise analytical models that can be used in the design of this type of connection considering both safety and economy.

\section{FINITE ELEMENT MODELLING}

The Finite Element (FE) package ABAQUS 6.11 [13] was used to simulate the behaviour of thin-walled carbon steel single shear bolted connections. The model consists of three components: test plate, pulling plate and bolts (as shown in Figure 2). Three dimensional continuum reduced integration element (C3D8R) [13] were selected to simulate the three components of the model. This element is suitable for simulating highly nonlinear behaviour including contact and geometrical nonlinearities. The geometrical and materials properties of the model are identical to the specimens tested by Kim et al. [10]. Figure 3 and Table 1 present the geometrical and materials properties of the model components. The specimen name describes its geometrical properties. For example, T1.5E24 denotes that the thickness of the test plate is $1.5 \mathrm{~mm}$ and the end distance $(\mathrm{e} 1)$ is $24 \mathrm{~mm}$. The exact geometrical properties were used to generate the model. The material properties listed in Table 1 were converted to true values and then fed to the FE model. The bolts and the pulling plate were simulated as elastic materials, whereas, the test plate was modelled as elastic plastic material using bilinear stressstrain relation [14].

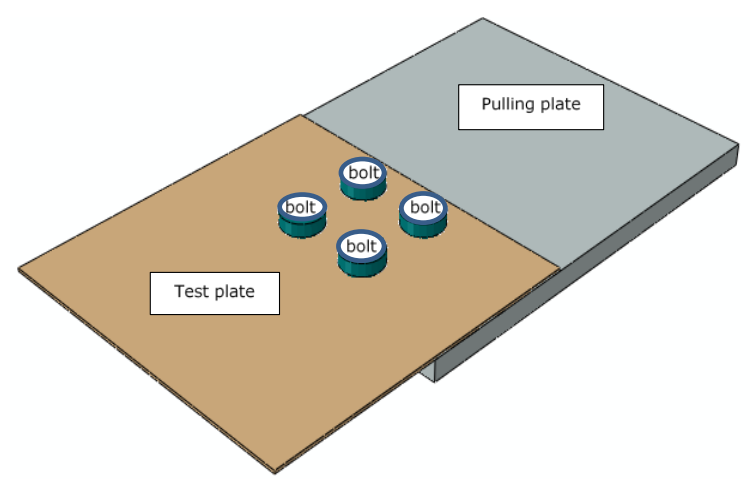

Figure 2: FE model components 


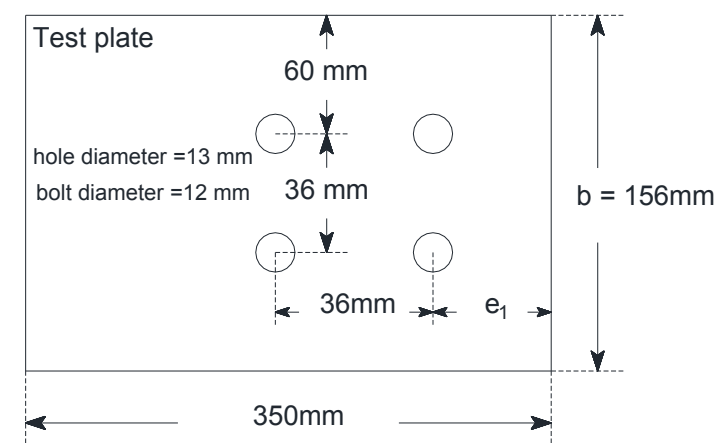

a. Test plate

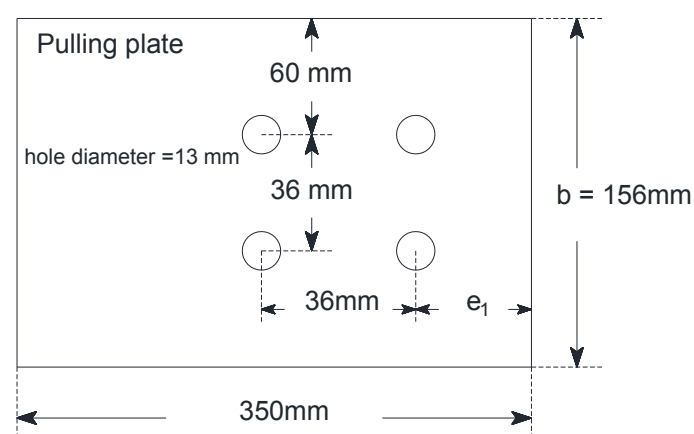

b. Pulling plate (thickness $=10 \mathrm{~mm})$

Figure 3: Model geometry of specimens tested by Kim et al. [10]

Table 1: Material properties of specimens tested by Kim et al. [10]

\begin{tabular}{|c|c|c|c|c|}
\hline Specimens & $\begin{array}{c}\text { Young's modulus } \\
\mathrm{E}(\mathrm{GPa})\end{array}$ & $\begin{array}{c}\text { Yield strength } \\
\mathrm{f}_{\mathrm{y}}(\mathrm{MPa})\end{array}$ & $\begin{array}{c}\text { Ultimate strength } \\
\mathrm{f}_{\mathrm{u}}(\mathrm{MPa})\end{array}$ & $\begin{array}{c}\text { Elongation } \\
\% \\
\end{array}$ \\
\hline $\mathrm{T} 1.5 \mathrm{E} 12, \mathrm{~T} 1.5 \mathrm{E} 18, \mathrm{~T} 1.5 \mathrm{E} 24 \& \mathrm{~T} 1.5 \mathrm{E} 36$ & 201 & 344 & 434 & 34.67 \\
\hline T3.0E24, T3.0E30, T3.0E $36, \mathrm{~T} 3.0 \mathrm{E} 48 \& \mathrm{~T} 3.0 \mathrm{E} 60$ & 213 & 345 & 498 & 32.00 \\
\hline T6.0Е36, T6.0Е48, Т6.0Е48, T6.0Е54 \& T6.0Е60 & 193 & 222 & 334 & 49.90 \\
\hline
\end{tabular}

Surface to surface contact algorithm was used to simulate the contact between the different parts of the model. Both hard and tangential contacts existed in the model. The friction coefficient was considered equal to 0.45 [15]. To avoid stress concentration at the test plate, the support boundary condition was distributed over an area equal to $b \times 20 \mathrm{~mm}$, where $b$ is the width of the test plate, Figure 4. Mesh sensitivity analysis was performed to identify the optimum element size and it was found that mesh size $0.5 \mathrm{t}$ ( $\mathrm{t}$ is the test plate thickness) is suitable to use at the area close to the holes and the rest of the model could be meshed using coarser element (Figure 5). 


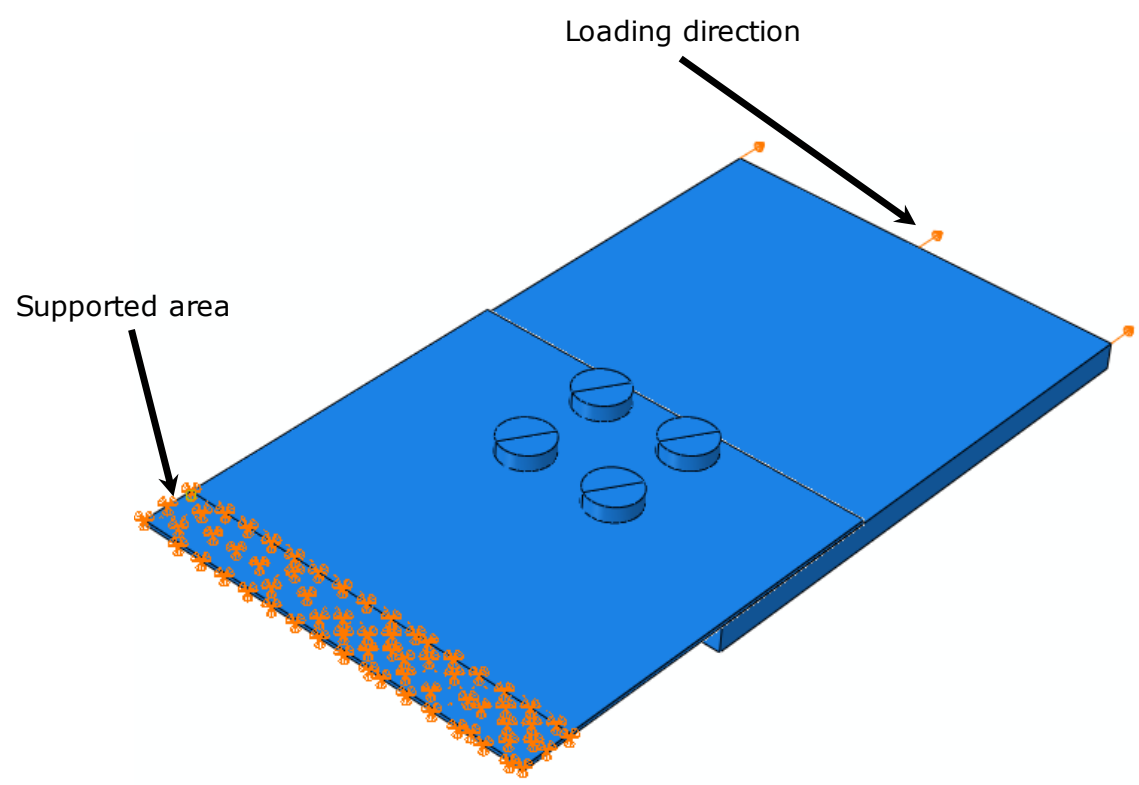

Figure 4: Model boundary conditions

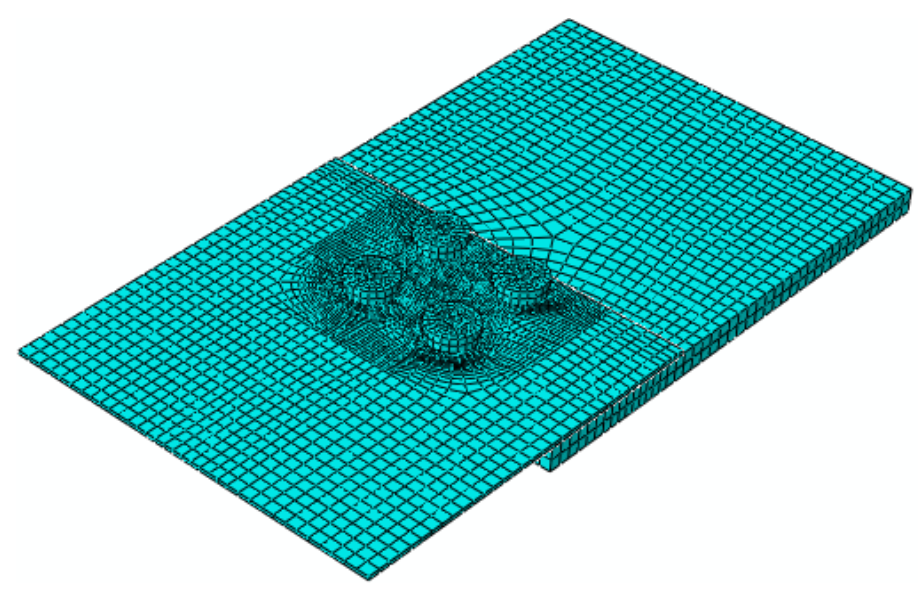

Figure 5: Model mesh

\section{FE MODEL VALIDATION}

In order to verify the accuracy of the numerical model, its results were compared with experimental data and observations from the literature. Figure 6 shows a comparison between the FE results and experimental data reported by Kim et al. [10]. The general pattern of the FE curves shows good correlation with the experimental data. 


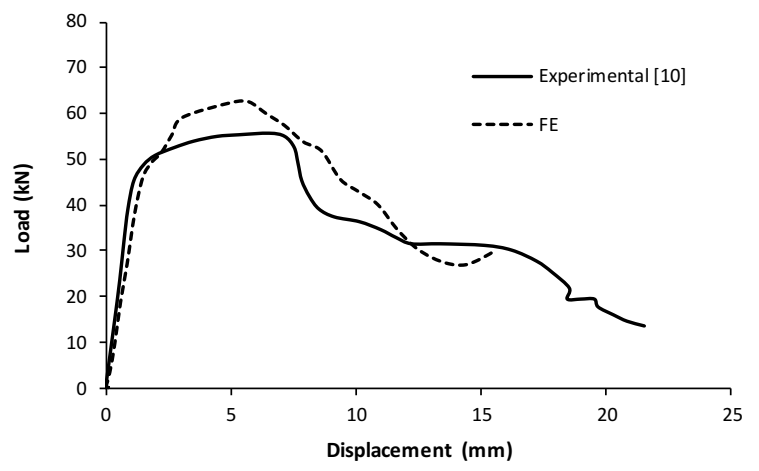

a. T1.5E12

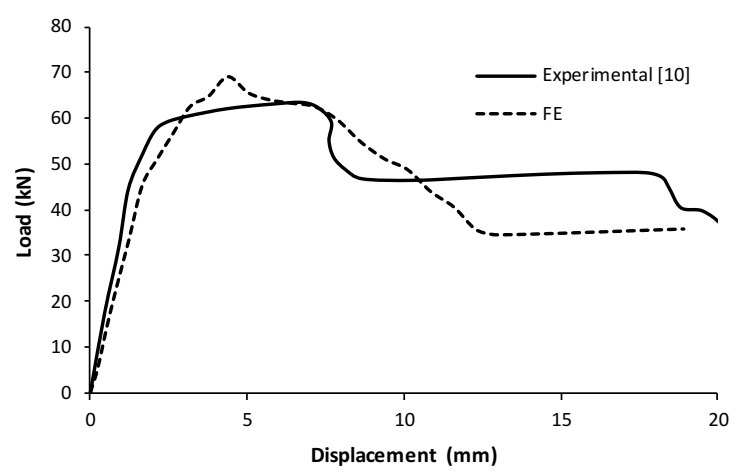

c. T1.5E24

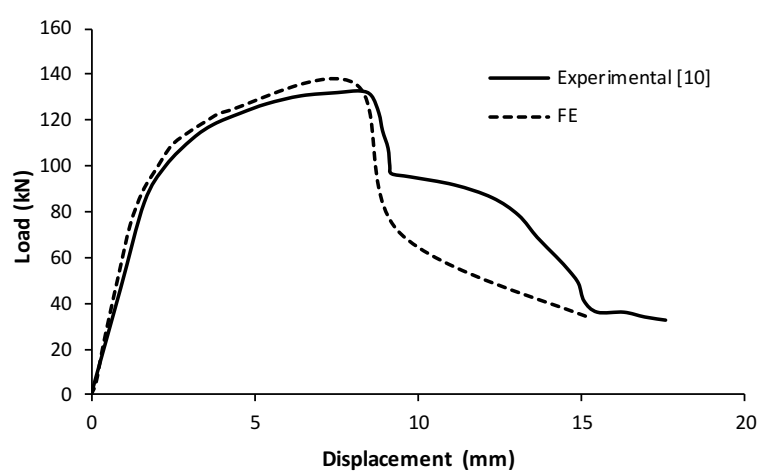

e. T3.0E24

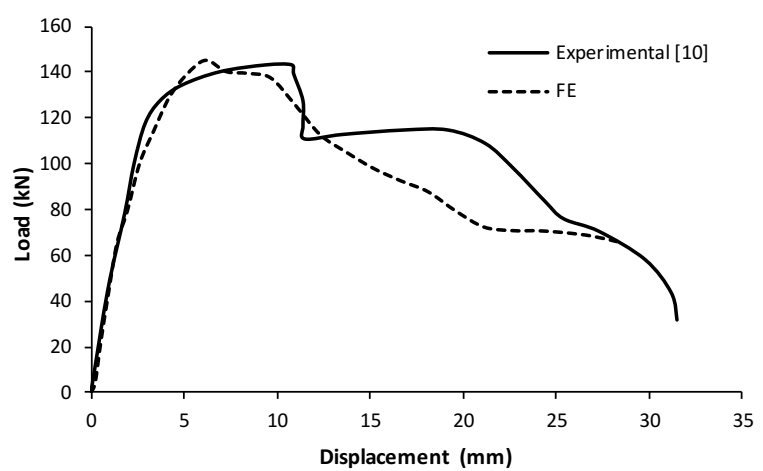

g. T3.0E36

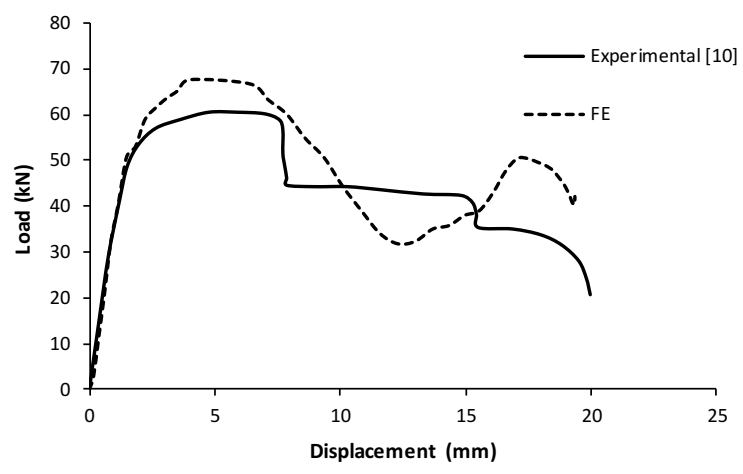

b. $\mathrm{T} 1.5 \mathrm{E} 18$

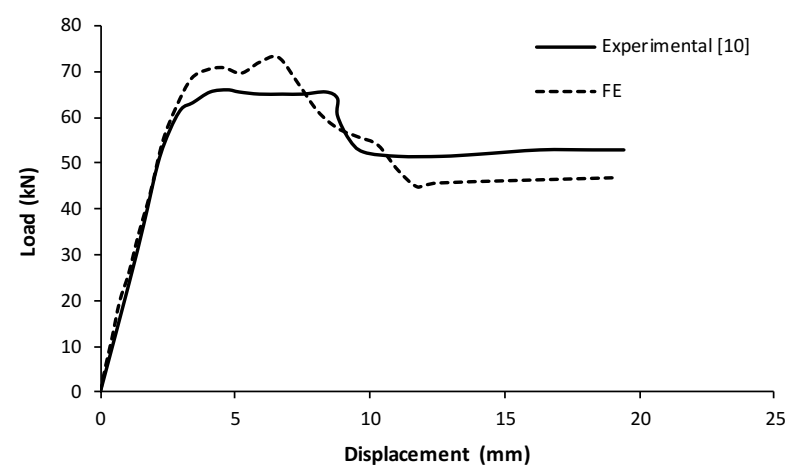

d. T1.5E36

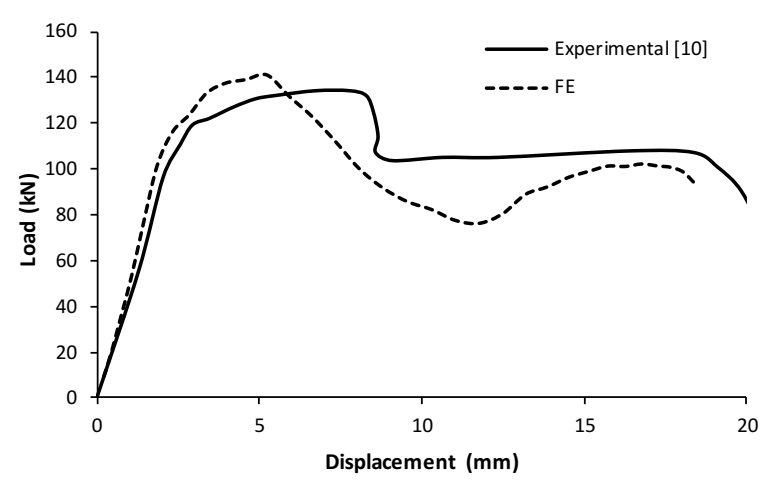

f. $\mathrm{T} 3.0 \mathrm{E} 30$

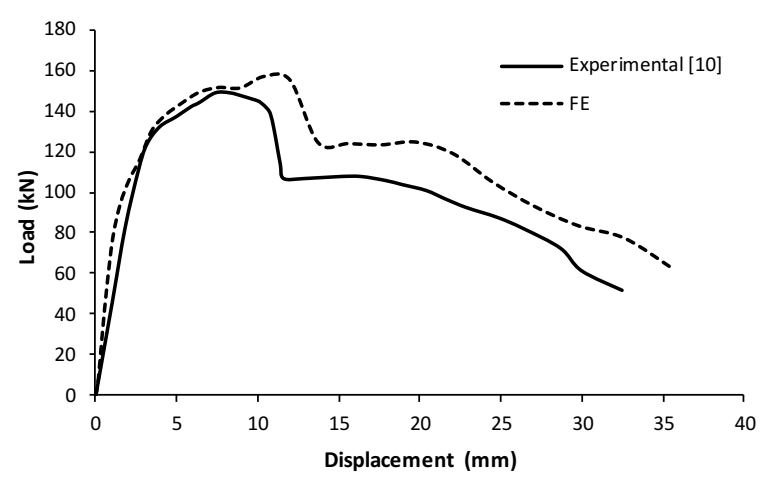

h. T3.0E48 


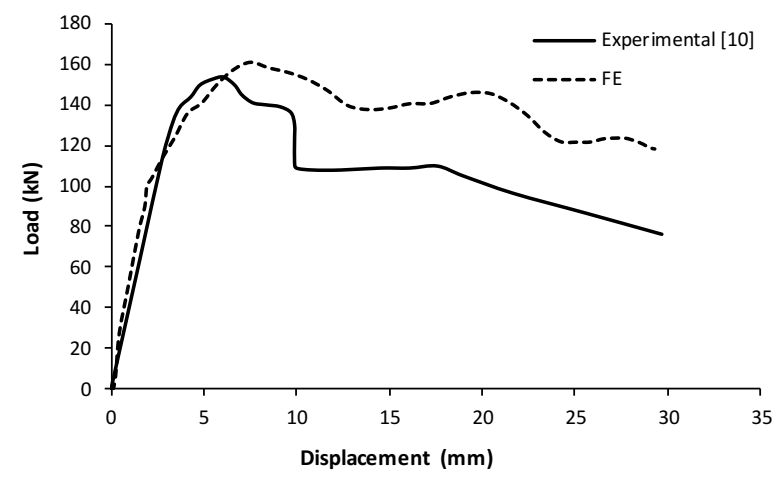

i. T3.0E60

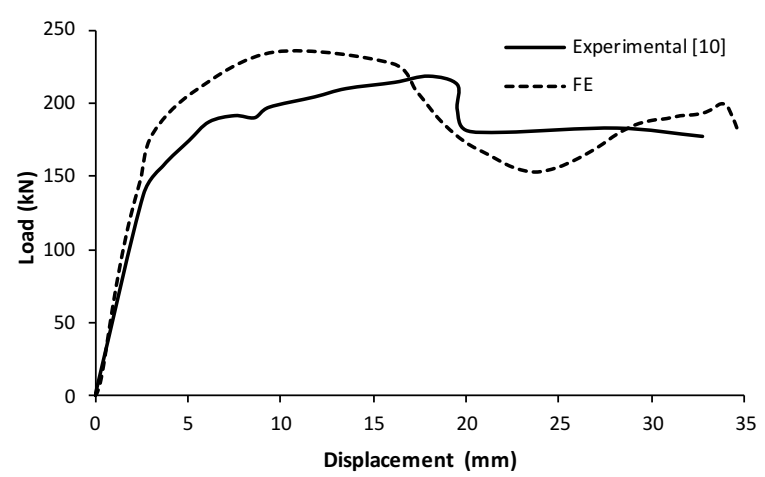

k. T6.0E48

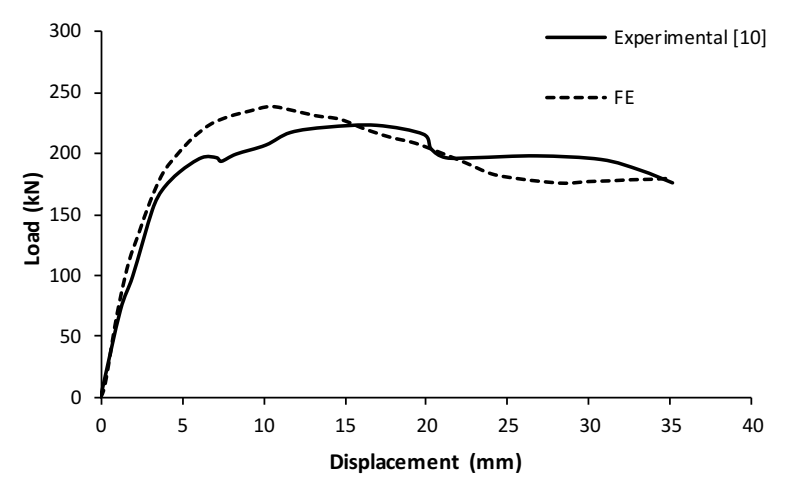

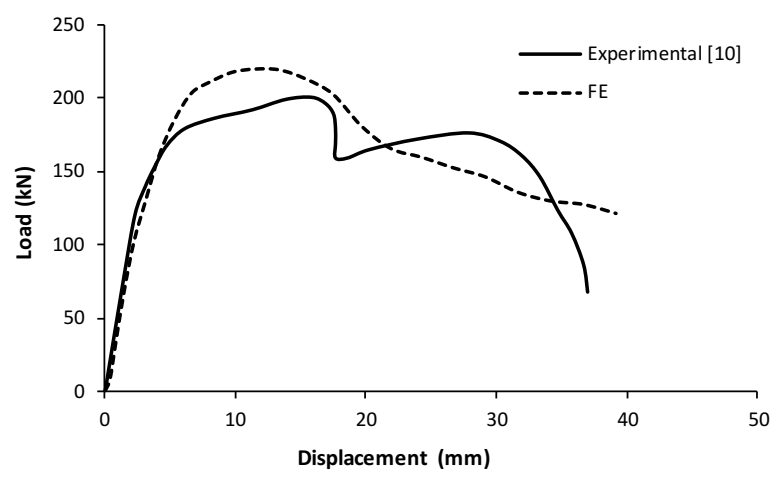

j. T6.0E36

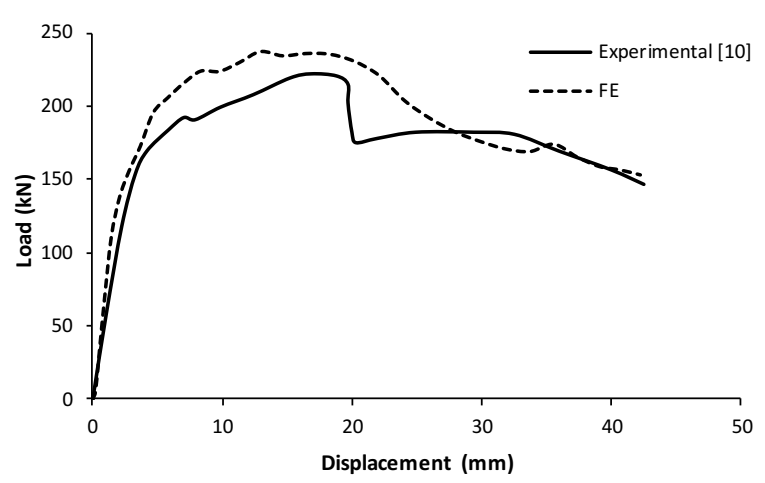

1. T6.0E54

m. T6.0E60

Figure 6: Load displacement curves FE Vs. experimental data from Kim et al [10].

Table 2 summarises a comparison between the ultimate strength $\left(\mathrm{P}_{\mathrm{u}}\right)$ and curling displacement $\left(\Delta_{\mathrm{c}}\right)$ from FE analysis and experimental data [10]. The maximum mean value of ratio of finite element ultimate strength to the experimental ultimate strength ( $\mathrm{Puf} / \mathrm{Pue})$ and corresponding coefficient of variation are 1.08 and 0.037 respectively. Figure 7 shows the ability of the FE model to capture the failure mode accurately. This indicates that the FE model can accurately simulate the behaviour of the connection.

Table 2: Ultimate strength and curling displacement FE Vs. experimental from Kim et al [10] 


\begin{tabular}{|c|c|c|c|c|c|c|}
\hline \multirow{2}{*}{ Specimens } & \multicolumn{3}{|c|}{ Ultimate strength $\mathrm{P}_{\mathrm{u}}$} & \multicolumn{2}{|c|}{ Curling displacement at $P_{u}$} & \multirow[b]{2}{*}{$\Delta_{\mathrm{c}} / \Delta_{\mathrm{ce}}$} \\
\hline & Exp. $\mathrm{P}_{\mathrm{ue}} \mathrm{kN}$ & $\mathrm{FE} \mathrm{P}_{\mathrm{uf}} \mathrm{kN}$ & $\mathrm{P}_{\mathrm{uf}} / \mathrm{P}_{\mathrm{ue}}$ & Exp. $\Delta_{\mathrm{ce}} \mathrm{mm}$ & $\mathrm{FE} \Delta_{\mathrm{cf}} \mathrm{mm}$ & \\
\hline $\mathrm{T} 1.5 \mathrm{E} 12$ & 54.68 & 62.58 & 1.14 & --- & --- & --- \\
\hline $\mathrm{T} 1.5 \mathrm{E} 18$ & 60.50 & 67.53 & 1.12 & --- & --- & --- \\
\hline $\mathrm{T} 1.5 \mathrm{E} 24$ & 61.28 & 69.08 & 1.13 & --- & --- & --- \\
\hline T1.5E36 & 66.12 & 73.10 & 1.11 & 3.22 & 3.15 & 0.98 \\
\hline $\mathrm{T} 3.0 \mathrm{E} 24$ & 131.38 & 138.40 & 1.05 & --- & --- & --- \\
\hline $\mathrm{T} 3.0 \mathrm{E} 30$ & 134.52 & 141.10 & 1.05 & --- & --- & --- \\
\hline $\mathrm{T} 3.0 \mathrm{E} 36$ & 142.92 & 145.40 & 1.02 & 3.12 & 2.79 & 0.89 \\
\hline $\mathrm{T} 3.0 \mathrm{E} 48$ & 148.63 & 157.29 & 1.06 & 5.46 & 4.71 & 0.86 \\
\hline T3.0E60 & 153.57 & 161.07 & 1.05 & 0.55 & 0.50 & 0.91 \\
\hline T6.0E36 & 201.00 & 220.06 & 1.09 & 0.87 & 0.81 & 0.93 \\
\hline $\mathrm{T} 6.0 \mathrm{E} 48$ & 215.54 & 235.12 & 1.09 & 1.22 & 1.13 & 0.93 \\
\hline T6.0E54 & 220.50 & 237.26 & 1.08 & 1.08 & 0.98 & 0.91 \\
\hline \multirow[t]{3}{*}{ - - } & Mean & 238.18 & $\frac{1.07}{1.08}$ & 0.95 & 0.85 & $\begin{array}{c}0.89 \\
--9.91\end{array}$ \\
\hline & \multicolumn{2}{|c|}{ Standard deviation } & 0.036 & & & 0.034 \\
\hline & \multicolumn{2}{|c|}{ Coefficient of variation } & 0.034 & & & 0.037 \\
\hline
\end{tabular}
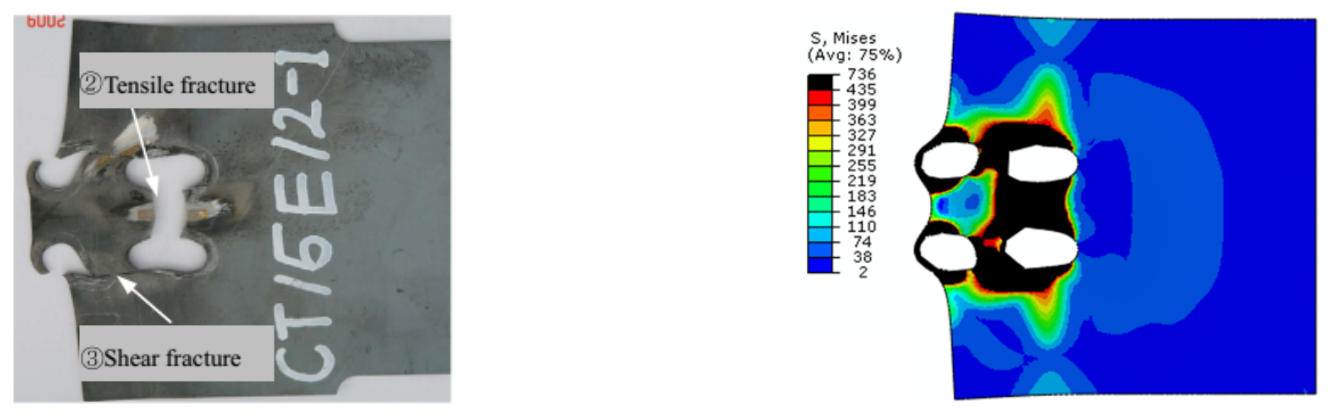

T1.5E12
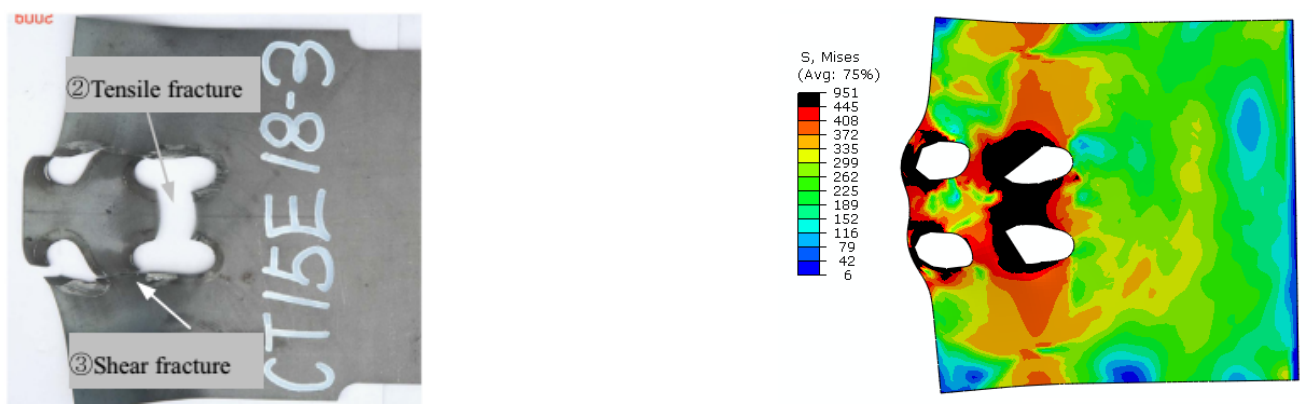

T1.5E18 

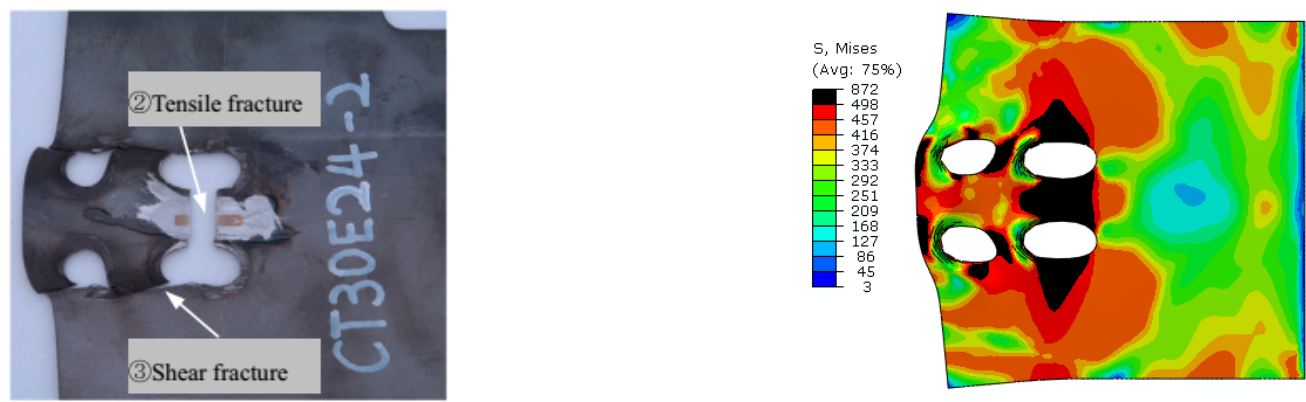

T30E24
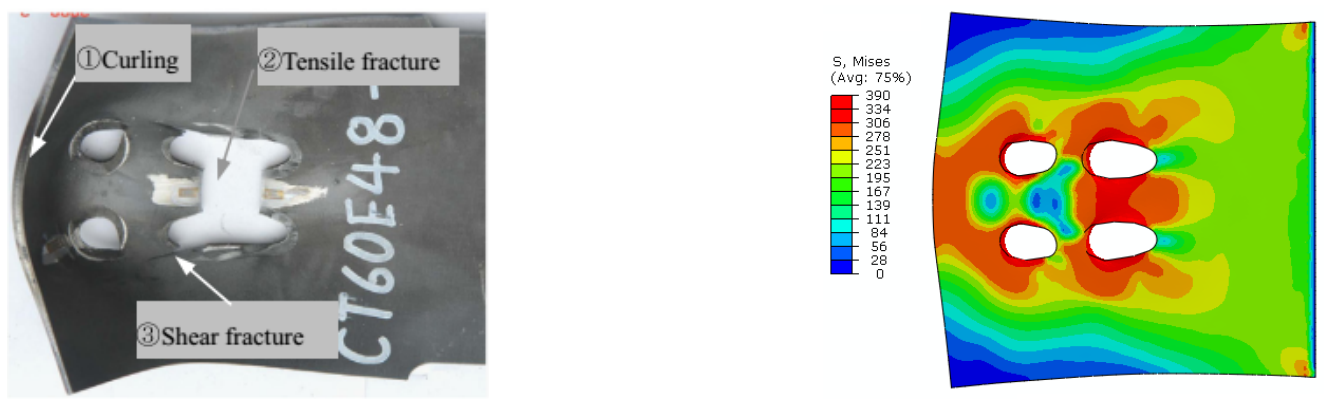

T60E48

Figure 7: Failure modes FE versus experimental from Kim et al [10]

\section{FE ANALYSIS AND PARAMETRIC STUDY}

The parametric study investigates the effect of plate thickness, end distance $e_{1}$ and the constraint of curling displacement. The other parameters are kept constant for all specimens. The bolt gauge and pitch distances are equal to $36 \mathrm{~mm}$. The bolt diameter is $12 \mathrm{~mm}$ and the hole diameter is $13 \mathrm{~mm}$. The edge distance $\mathrm{e}_{2}$ is equal to $60 \mathrm{~mm}$. The Young modulus of elasticity is $201 \mathrm{GPa}$, the yield strength is $344 \mathrm{MP}$, the ultimate strength is $434 \mathrm{MPaa}$ and the fracture elongation is $34.67 \%$.

\subsection{Failure Criteria and Curling}

Experimental evidence, [10], confirmed that the ultimate strength in thin-walled carbon steel is governed by the fracture and the curling of the steel plate. In previous numerical analysis $[5,14,16,17]$, it was stated that the fracture initiates when the direct stress or strain in the steel plate approaches its ultimate values. Hence, bolted joints reach their ultimate limit state (ultimate strength) when the stress or strain becomes greater or equal to the true values. Accordingly, the following assumption is adopted to predict the failure criteria:

$\frac{\sigma}{\sigma_{t \max }} \geq 1.0 \quad \rightarrow$ fracture exists in the plate

where $\sigma$ is the direct stress and $\sigma_{t \max }$ is the maximum stress (ultimate stress).

The FE results showed that there are five possible modes of failure that could govern the behaviour of the bolted connections in thin-walled carbon steel: 
- Mode 1 (Figure 8, a): Tensile fracture of the plate between the holes transvers to the loading direction, shear fracture between the holes parallel to the loading direction and bending fracture at the end distance parallel to the loading direction.

- Mode 2 (Figure 8, b): Tensile fracture of the plate between the holes transvers to the loading direction, shear fracture between the holes parallel to the loading direction and bending yielding at the end distance parallel to the loading direction.

- Mode 3 (Figure 8, c): Tensile yielding in the plate between the holes transvers to the loading direction, shear yielding between the holes parallel to the loading direction and bending yielding in the end distance parallel to the loading direction.

- Mode 4 (Figure 8, d and f): Curling, tensile yielding in the plate between the holes transvers to the loading direction and bending yielding in the end distance parallel to the loading direction. It is clear that the curling prevents the shear yielding between the holes parallel to the loading direction.

- $\quad$ Mode 5 (Figure 8, e): Gross yielding across the width of the plate transvers to the loading direction.

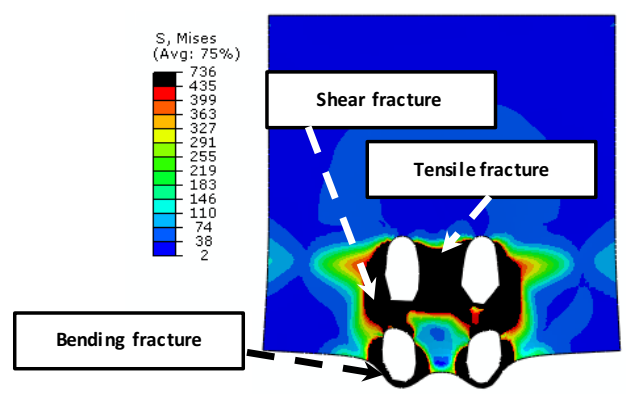

T1.5E12

a. Mode 1

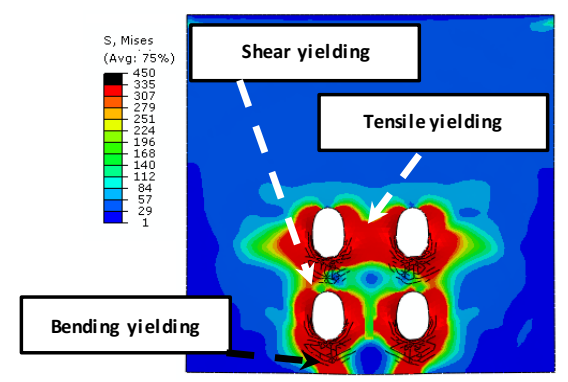

T3.5E24

c. Mode 3

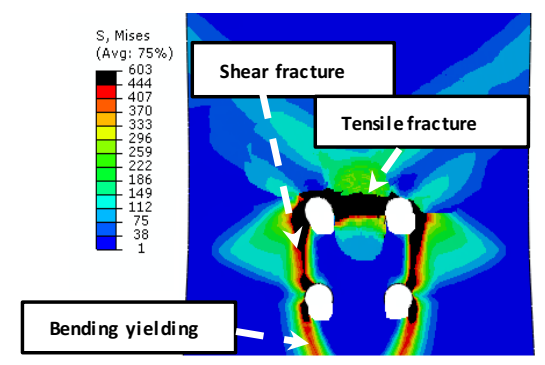

T2.0E18

b. Mode 2

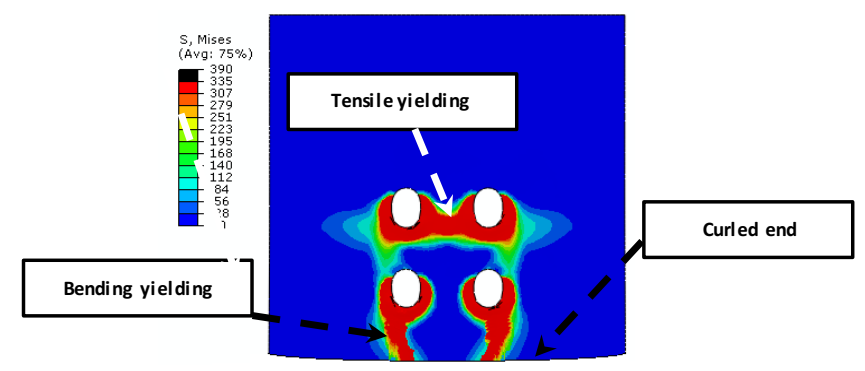

T5.5E30

d. Mode 4 


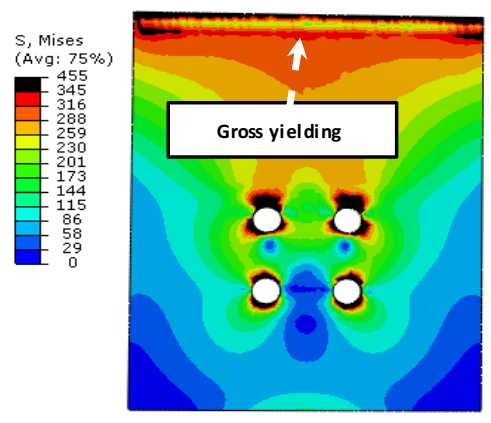

T4.5E60

e. Mode 5

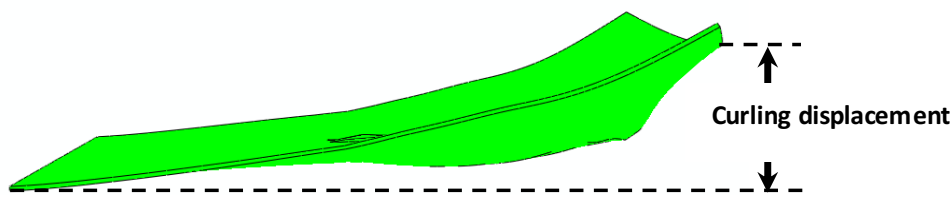

$\mathrm{T} 2.5 \mathrm{E} 36$

\section{f. Curling}

\section{Figure 8: Failure modes}

\subsection{Influence of end distance}

Figure 9 shows the effect of end distance on the ultimate strength of the bolted connections in thin-walled carbon steel. The end distance was varied from $12 \mathrm{~mm}$ to $60 \mathrm{~mm}$ for six plates with thickness of $1.5,2.5,3.5,4.5,5.5$, and 6.5 millimetres. The results present clear improvement in the connection strength with the increase of the end distance. However, the improvement becomes negligible after edge distance of $42 \mathrm{~mm}$ for plate thickness less than or equal to $3.5 \mathrm{~mm}$ and $48 \mathrm{~mm}$ for plate thickness greater than $3.5 \mathrm{~mm}$. This could be attributed to the changing of failure mode to gross yielding in the plate transvers to the loading direction (Mode 5) at these end distances (Figure 10). Since Mode 5 is gross yielding mechanism and the connection strength does not depend on the end distance. Therefore, it is recommended that the maximum end distance measured parallel to the loading direction to be equal to 50 millimetres.

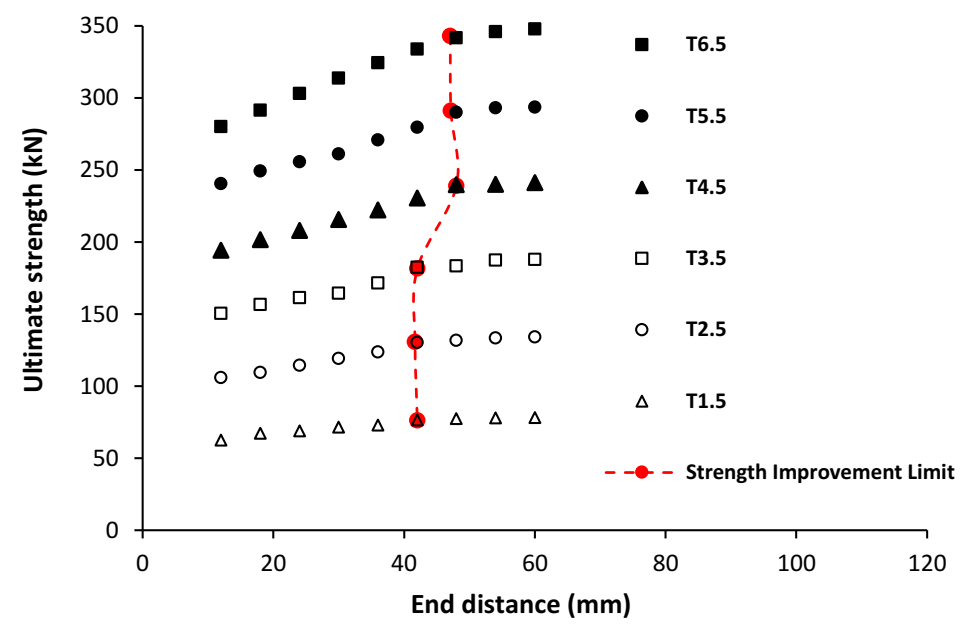

Figure 9: Effect of end distance on ultimate strength 


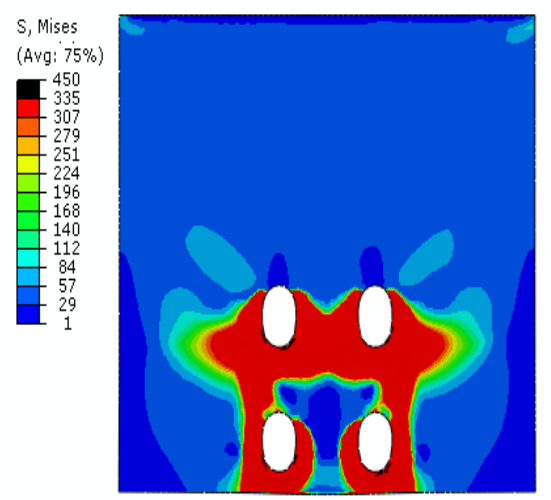

a. T6.5E12

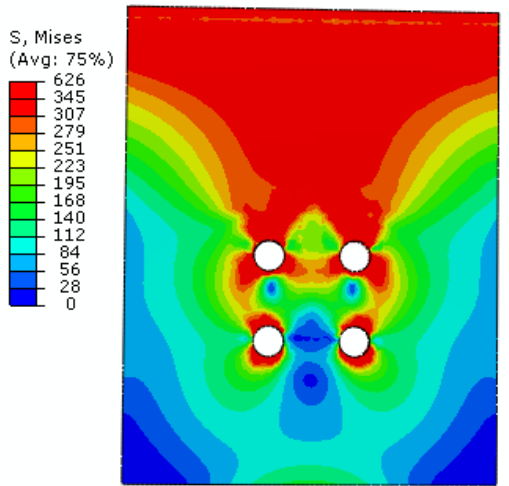

b. T6.5E60

Figure 10: Influence of edge distance on failure mode

\subsection{Influence of curling}

Curling could affect the connection performance in different manners. It could improve the buckling capacity of wide flange sections [18] or reduce the connection capacity [10]. A limit of $0.3 \mathrm{~mm}$ curling displacement was suggested by Kim et al. [6] as a failure criterion for single shear bolted connections in cold formed austenitic stainless steel. To investigate the effect of curling, the specimens that failed by curling (Mode 4) were reanalysed with a constraint against curling. The constraint was added to the face of the specimens along the end distance to prevent any out of plane displacement in the direction of the plate thickness. The letter $\mathrm{S}$ was added to the end of the name of the specimens to indicate this constraint. For example, T1.5E30 is free to curl specimen, whereas $\mathrm{T} 1.5 \mathrm{E} 30 \mathrm{~S}$ is constrained against curling specimen. Figure 11 shows that the existence of curling could limit the connection strength. The maximum reduction in the connection strength due curling is equal to $12 \%$ (Table 3). For the curled specimens, the load displacement relation shows sharp drop in the strength after reaching the ultimate capacity. However, the drop in the strength was softer for constrained specimens. Also it was found that the presence of curling could change the strain distribution around the bolt holes (Figure 12). Table 4 presents that Mode4 (curling mode) exists only when the curling displacement at $\mathrm{Pu}$ is larger than $0.5 \mathrm{~mm}$. Therefore, the curling displacement can be considered as a failure criterion only when it exceeds $0.5 \mathrm{~mm}$ before the presence of any of the failure modes described above. 


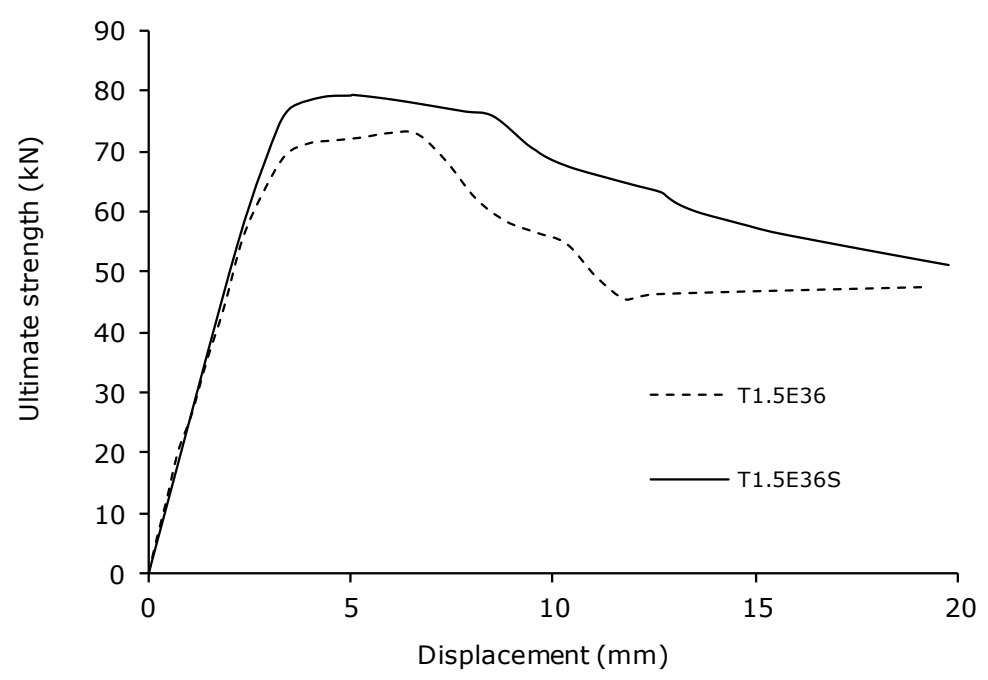

a. T1.5E36 vs. T1.5E36S

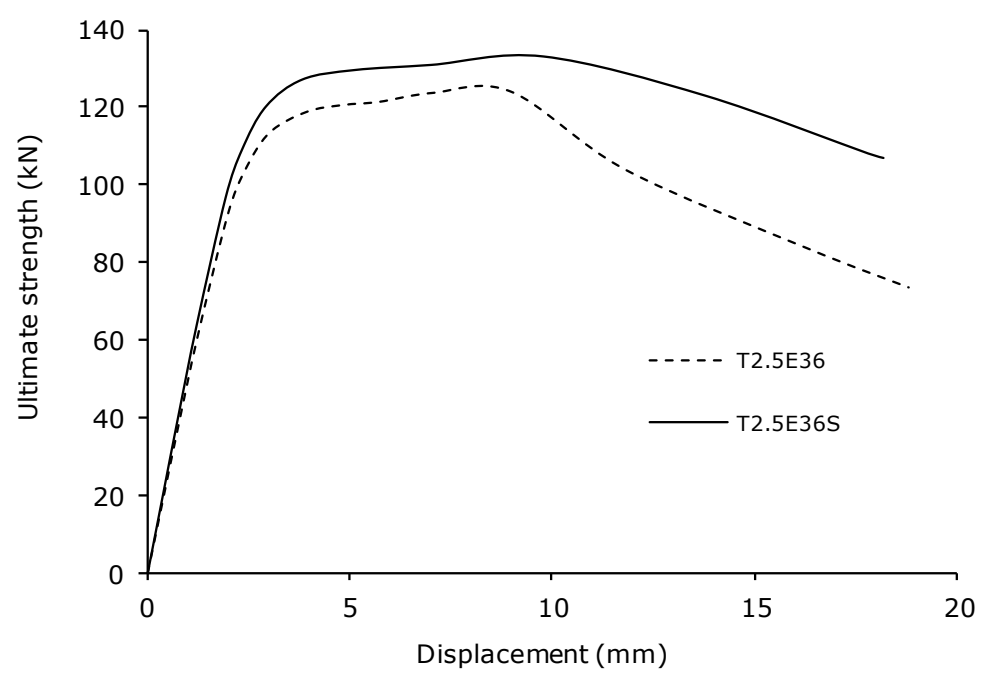

b. T2.5E30 vs. T2.5E $30 \mathrm{~S}$

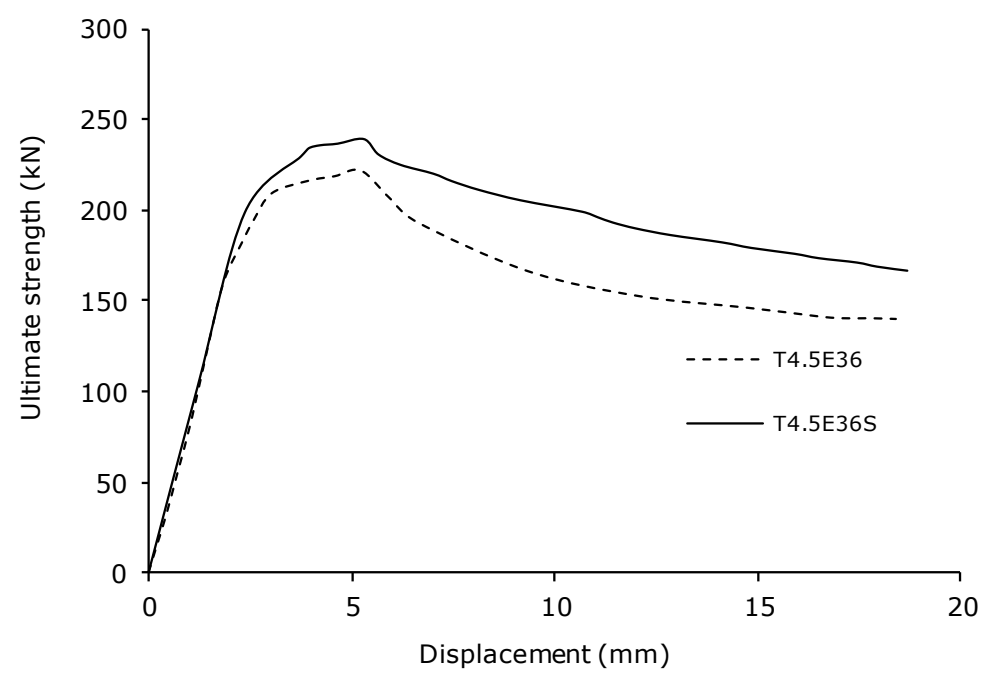

c. T4.5E36 vs. T4.5E36S 


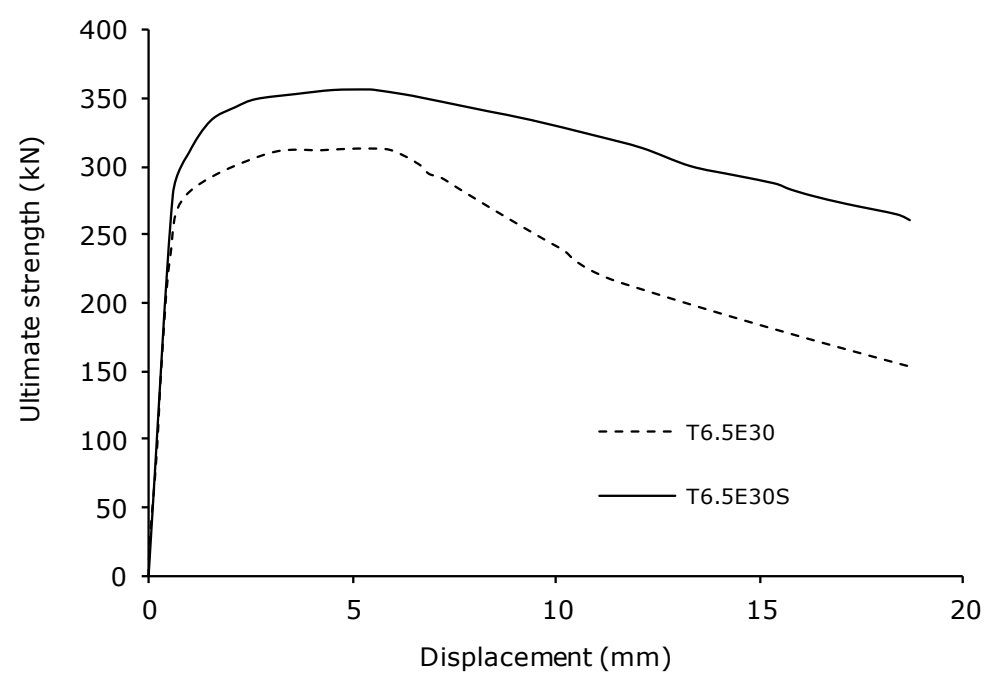

d. T6.5E30 vs. T6.5E30S

Figure 11: Influence of curling on the connection behaviour

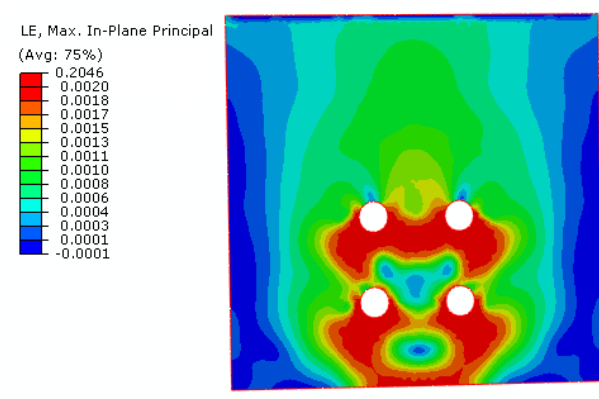

a. $\mathrm{T} 5.5 \mathrm{E} 30$

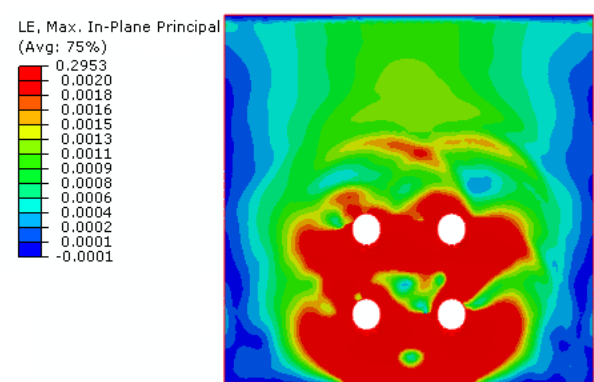

b. T5.5E30S

Figure 12: Influence of curling on strain distribution

Table 3: The ultimate strength of curled and uncurled specimens

\begin{tabular}{ccccc}
\hline Curled Specimens & $\mathrm{P}_{\mathrm{u} \text { curled }}$ & Uncurled Specimens & $\mathrm{P}_{\mathrm{u} \text { uncurled }}$ & $\mathrm{P}_{\mathrm{u} \text { curled }} / \mathrm{P}_{\mathrm{u} u \text { uncurled }}$ \\
\hline $\mathrm{T} 1.5 \mathrm{E} 30$ & 71.622 & $\mathrm{~T} 1.5 \mathrm{E} 30 \mathrm{~S}$ & 78.712 & 0.91 \\
$\mathrm{~T} 1.5 \mathrm{E} 36$ & 73.102 & $\mathrm{~T} 1.5 \mathrm{E} 36 \mathrm{~S}$ & 79.325 & 0.92 \\
$\mathrm{~T} 2.0 \mathrm{E} 30$ & 92.561 & $\mathrm{~T} 2.0 \mathrm{E} 30 \mathrm{~S}$ & 104.587 & 0.89 \\
$\mathrm{~T} 2.0 \mathrm{E} 36$ & 98.987 & $\mathrm{~T} 2.0 \mathrm{E} 36 \mathrm{~S}$ & 106.358 & 0.93 \\
$\mathrm{~T} 2.5 \mathrm{E} 30$ & 119.359 & $\mathrm{~T} 2.5 \mathrm{E} 30 \mathrm{~S}$ & 131.618 & 0.91 \\
$\mathrm{~T} 2.5 \mathrm{E} 36$ & 123.767 & $\mathrm{~T} 2.5 \mathrm{E} 36 \mathrm{~S}$ & 133.122 & 0.93 \\
$\mathrm{~T} 3.0 \mathrm{E} 30$ & 143.625 & $\mathrm{~T} 3.0 \mathrm{E} 30 \mathrm{~S}$ & 158.125 & 0.91 \\
$\mathrm{~T} 3.0 \mathrm{E} 36$ & 152.014 & $\mathrm{~T} 3.0 \mathrm{E} 36 \mathrm{~S}$ & 159.512 & 0.95 \\
$\mathrm{~T} 3.5 \mathrm{E} 30$ & 164.612 & $\mathrm{~T} 3.5 \mathrm{E} 30 \mathrm{~S}$ & 184.254 & 0.89 \\
$\mathrm{~T} 3.5 \mathrm{E} 36$ & 171.630 & $\mathrm{~T} 3.5 \mathrm{E} 36 \mathrm{~S}$ & 183.614 & 0.93 \\
$\mathrm{~T} 4.0 \mathrm{E} 30$ & 189.222 & $\mathrm{~T} 4.0 \mathrm{E} 30 \mathrm{~S}$ & 214.987 & 0.88
\end{tabular}




\begin{tabular}{lllll}
$\mathrm{T} 4.0 \mathrm{E} 36$ & 198.954 & $\mathrm{~T} 4.0 \mathrm{E} 36 \mathrm{~S}$ & 213.554 & 0.93 \\
$\mathrm{~T} 4.0 \mathrm{E} 42$ & 212.106 & $\mathrm{~T} 4.0 \mathrm{E} 42 \mathrm{~S}$ & 216.546 & 0.98 \\
$\mathrm{~T} 4.5 \mathrm{E} 30$ & 215.723 & $\mathrm{~T} 4.5 \mathrm{E} 30 \mathrm{~S}$ & 238.156 & 0.91 \\
$\mathrm{~T} 4.5 \mathrm{E} 36$ & 222.354 & $\mathrm{~T} 4.5 \mathrm{E} 36 \mathrm{~S}$ & 235.751 & 0.94 \\
$\mathrm{~T} 4.5 \mathrm{E} 42$ & 230.789 & $\mathrm{~T} 4.5 \mathrm{E} 42 \mathrm{~S}$ & 244.381 & 0.94 \\
$\mathrm{~T} 5.0 \mathrm{E} 30$ & 238.687 & $\mathrm{~T} 5.0 \mathrm{E} 30 \mathrm{~S}$ & 268.147 & 0.89 \\
$\mathrm{~T} 5.0 \mathrm{E} 36$ & 248.729 & $\mathrm{~T} 5.0 \mathrm{E} 36 \mathrm{~S}$ & 266.584 & 0.93 \\
$\mathrm{~T} 5.0 \mathrm{E} 42$ & 257.798 & $\mathrm{~T} 5.0 \mathrm{E} 42 \mathrm{~S}$ & 270.541 & 0.95 \\
$\mathrm{~T} 5.5 \mathrm{E} 30$ & 261.189 & $\mathrm{~T} 5.5 \mathrm{E} 30 \mathrm{~S}$ & 294.872 & 0.89 \\
$\mathrm{~T} 5.5 \mathrm{E} 36$ & 271.051 & $\mathrm{~T} 5.5 \mathrm{E} 36 \mathrm{~S}$ & 296.175 & 0.92 \\
$\mathrm{~T} 5.5 \mathrm{E} 42$ & 279.629 & $\mathrm{~T} 5.5 \mathrm{E} 42 \mathrm{~S}$ & 296.548 & 0.94 \\
$\mathrm{~T} 6.0 \mathrm{E} 30$ & 285.876 & $\mathrm{~T} 6.0 \mathrm{E} 30 \mathrm{~S}$ & 322.144 & 0.89 \\
$\mathrm{~T} 6.0 \mathrm{E} 36$ & 298.658 & $\mathrm{~T} 6.0 \mathrm{E} 36 \mathrm{~S}$ & 322.555 & 0.93 \\
$\mathrm{~T} 6.0 \mathrm{E} 42$ & 315.586 & $\mathrm{~T} 6.0 \mathrm{E} 42 \mathrm{~S}$ & 323.546 & 0.98 \\
$\mathrm{~T} 6.5 \mathrm{E} 30$ & 313.737 & $\mathrm{~T} 6.5 \mathrm{E} 30 \mathrm{~S}$ & 355.996 & 0.88 \\
$\mathrm{~T} 6.5 \mathrm{E} 36$ & 324.402 & $\mathrm{~T} 6.5 \mathrm{E} 36 \mathrm{~S}$ & 350.248 & 0.93 \\
$\mathrm{~T} 6.5 \mathrm{E} 42$ & 333.942 & $\mathrm{~T} 6.5 \mathrm{E} 42 \mathrm{~S}$ & 351.698 & 0.95 \\
\hline
\end{tabular}

Table 4: Curling displacement

\begin{tabular}{|c|c|c|c|c|c|c|c|c|}
\hline Specimen & $\begin{array}{c}\text { Curling } \\
\text { displacement } \\
\text { at } \mathrm{P}_{\mathrm{u}}(\mathrm{mm})\end{array}$ & $\begin{array}{c}\text { Failure } \\
\text { mode }\end{array}$ & Specimen & $\begin{array}{c}\text { Curling } \\
\text { displacement } \\
\text { at } P_{\mathrm{u}}(\mathrm{mm})\end{array}$ & $\begin{array}{c}\text { Failure } \\
\text { mode }\end{array}$ & Specimen & $\begin{array}{c}\text { Curling } \\
\text { displacement } \\
\text { at } \mathrm{P}_{\mathrm{u}}(\mathrm{mm})\end{array}$ & $\begin{array}{c}\text { Failure } \\
\text { mode }\end{array}$ \\
\hline $\mathrm{T} 1.5 \mathrm{E} 12$ & 0.146 & Mode 1 & T3.0E48 & 0.382 & Mode 5 & T5.0E30 & 0.662 & Mode 4 \\
\hline $\mathrm{T} 1.5 \mathrm{E} 18$ & 0.338 & Mode 2 & T3.0E54 & 0.304 & Mode 5 & T5.0E36 & 0.733 & Mode 4 \\
\hline T1.5E24 & 0.434 & Mode 3 & Т3.0E60 & 0.107 & Mode 5 & T5.0E42 & 0.683 & Mode 4 \\
\hline T1.5E30 & 0.532 & Mode 4 & $\mathrm{~T} 3.5 \mathrm{E} 12$ & 0.154 & Mode 1 & T5.0E48 & 0.456 & Mode 5 \\
\hline T1.5E36 & 0.543 & Mode 4 & $\mathrm{~T} 3.5 \mathrm{E} 18$ & 0.354 & Mode 2 & T5.0E54 & 0.418 & Mode 5 \\
\hline $\mathrm{T} 1.5 \mathrm{E} 42$ & 0.434 & Mode 5 & T3.5E24 & 0.456 & Mode 3 & T5.0E60 & 0.147 & Mode 5 \\
\hline $\mathrm{T} 1.5 \mathrm{E} 48$ & 0.389 & Mode 5 & T3.5E30 & 0.559 & Mode 4 & $\mathrm{~T} 5.5 \mathrm{E} 12$ & 0.184 & Mode 1 \\
\hline T1.5E54 & 0.310 & Mode 5 & T3.5E36 & 0.570 & Mode 4 & T5.5E18 & 0.425 & Mode 2 \\
\hline T1.5E60 & 0.109 & Mode 5 & $\mathrm{~T} 3.5 \mathrm{E} 42$ & 0.456 & Mode 5 & T5.5E24 & 0.442 & Mode 3 \\
\hline $\mathrm{T} 2.0 \mathrm{E} 12$ & 0.145 & Mode 1 & T3.5E48 & 0.408 & Mode 5 & T5.5E30 & 0.617 & Mode 4 \\
\hline $\mathrm{T} 2.0 \mathrm{E} 18$ & 0.334 & Mode 2 & T3.5E54 & 0.325 & Mode 5 & T5.5E36 & 0.684 & Mode 4 \\
\hline $\mathrm{T} 2.0 \mathrm{E} 24$ & 0.430 & Mode 3 & T3.5E60 & 0.114 & Mode 5 & T5.5E42 & 0.637 & Mode 4 \\
\hline T2.0E30 & 0.527 & Mode 4 & $\mathrm{~T} 4.0 \mathrm{E} 12$ & 0.165 & Mode 1 & T5.5E48 & 0.425 & Mode 5 \\
\hline T2.0E36 & 0.537 & Mode 4 & T4.0E18 & 0.380 & Mode 2 & T5.5E54 & 0.390 & Mode 5 \\
\hline $\mathrm{T} 2.0 \mathrm{E} 42$ & 0.430 & Mode 5 & $\mathrm{~T} 4.0 \mathrm{E} 24$ & 0.488 & Mode 3 & T5.5E60 & 0.137 & Mode 5 \\
\hline $\mathrm{T} 2.0 \mathrm{E} 48$ & 0.385 & Mode 5 & T4.0E30 & 0.599 & Mode 4 & $\mathrm{~T} 6.0 \mathrm{E} 12$ & 0.169 & Mode 1 \\
\hline $\mathrm{T} 2.0 \mathrm{E} 54$ & 0.306 & Mode 5 & T4.0E36 & 0.611 & Mode 4 & T6.0E18 & 0.391 & Mode 2 \\
\hline T2.0E60 & 0.108 & Mode 5 & T4.0E42 & 0.585 & Mode 4 & T6.0E24 & 0.406 & Mode 3 \\
\hline $\mathrm{T} 2.5 \mathrm{E} 12$ & 0.148 & Mode 1 & $\mathrm{~T} 4.0 \mathrm{E} 48$ & 0.438 & Mode 5 & T6.0E30 & 0.567 & Mode 4 \\
\hline $\mathrm{T} 2.5 \mathrm{E} 18$ & 0.342 & Mode 2 & T4.0E54 & 0.348 & Mode 5 & T6.0E36 & 0.628 & Mode 4 \\
\hline
\end{tabular}




\begin{tabular}{|c|c|c|c|c|c|c|c|c|}
\hline Specimen & $\begin{array}{c}\text { Curling } \\
\text { displacement } \\
\text { at } \mathrm{P}_{\mathrm{u}}(\mathrm{mm}) \\
\end{array}$ & $\begin{array}{c}\text { Failure } \\
\text { mode }\end{array}$ & Specimen & $\begin{array}{c}\text { Curling } \\
\text { displacement } \\
\text { at } \mathrm{P}_{\mathrm{u}}(\mathrm{mm}) \\
\end{array}$ & $\begin{array}{c}\text { Failure } \\
\text { mode }\end{array}$ & Specimen & $\begin{array}{c}\text { Curling } \\
\text { displacement } \\
\text { at } \mathrm{P}_{\mathrm{u}}(\mathrm{mm}) \\
\end{array}$ & $\begin{array}{c}\text { Failure } \\
\text { mode }\end{array}$ \\
\hline $\mathrm{T} 2.5 \mathrm{E} 24$ & 0.439 & Mode 3 & T4.0E60 & 0.123 & Mode 5 & T6.0E42 & 0.585 & Mode 4 \\
\hline T2.5E30 & 0.539 & Mode 4 & $\mathrm{~T} 4.5 \mathrm{E} 12$ & 0.175 & Mode 1 & $\mathrm{~T} 6.0 \mathrm{E} 48$ & 0.391 & Mode 5 \\
\hline T2.5E36 & 0.550 & Mode 4 & $\mathrm{~T} 4.5 \mathrm{E} 18$ & 0.405 & Mode 2 & T6.0E54 & 0.358 & Mode 5 \\
\hline $\mathrm{T} 2.5 \mathrm{E} 42$ & 0.439 & Mode 5 & $\mathrm{~T} 4.5 \mathrm{E} 24$ & 0.467 & Mode 3 & T6.0E60 & 0.126 & Mode 5 \\
\hline $\mathrm{T} 2.5 \mathrm{E} 48$ & 0.394 & Mode 5 & T4.5E30 & 0.638 & Mode 4 & $\mathrm{~T} 6.5 \mathrm{E} 12$ & 0.161 & Mode 1 \\
\hline $\mathrm{T} 2.5 \mathrm{E} 54$ & 0.313 & Mode 5 & T4.5E36 & 0.651 & Mode 4 & T6.5E18 & 0.371 & Mode 2 \\
\hline $\mathrm{T} 2.5 \mathrm{E} 60$ & 0.110 & Mode 5 & T4.5E42 & 0.623 & Mode 4 & T6.5E24 & 0.386 & Mode 3 \\
\hline $\mathrm{T} 3.0 \mathrm{E} 12$ & 0.144 & Mode 1 & T4.5E48 & 0.467 & Mode 5 & T6.5E30 & 0.539 & Mode 4 \\
\hline T3.0E18 & 0.331 & Mode 2 & $\mathrm{~T} 4.5 \mathrm{E} 54$ & 0.371 & Mode 5 & T6.5E36 & 0.597 & Mode 4 \\
\hline T3.0E24 & 0.426 & Mode 3 & $\mathrm{~T} 4.5 \mathrm{E} 60$ & 0.131 & Mode 5 & T6.5E42 & 0.556 & Mode 4 \\
\hline T3.0E30 & 0.522 & Mode 4 & $\mathrm{~T} 5.0 \mathrm{E} 12$ & 0.197 & Mode 1 & T6.5E48 & 0.371 & Mode 5 \\
\hline T3.0E36 & 0.533 & Mode 4 & T5.0E18 & 0.456 & Mode 2 & T6.5E54 & 0.341 & Mode 5 \\
\hline $\mathrm{T} 3.0 \mathrm{E} 42$ & 0.426 & Mode 5 & T5.0E24 & 0.474 & Mode 3 & T6.5E60 & 0.120 & Mode 5 \\
\hline
\end{tabular}

\section{ESTIMATION OF ULTIMATE STRENGTH}

The design standards for steel structures such as Euro Code (EC3) [19, 20], American Iron and Steel Institute (AISI) specification[21], American Institute of Steel Construction (AISC) manual [22] provide design rules for calculating the strength of shear bolted connections. EC3 describes the ultimate strength of the connection by tensile fracture of net section area (Ant) and shear yielding of net section area (Ans).

$P_{u}=A_{n t} F_{u}+\frac{A_{n s} F_{y}}{\sqrt{3}}$

AISI [21] and AISC [22] define the ultimate strength of the connection by the minimum of equations 2 and 3

$P_{u}=A_{n t} F_{u}+0.6 A_{g s} F_{y}$

$P_{u}=A_{n t} F_{u}+0.6 A_{n s} F_{u}$

Where, $A g s$ is the gross area subject to shear.

Teh et al. in 2011 [23] suggested equation (4) for calculating the block shear fracture strength of bolted connections in cold-reduced steel sheets (G450). The equation considers both of net section tensile fracture and active shear fracture.

$P_{u}=A_{n t} F_{u}\left(0.9+0.1 \frac{d}{g}\right)+0.6 A_{a v} F_{y}$

Where, $A a v$ is the active gross area subject to shear $=2\left(L_{g v}-\left(\frac{n_{1}-1}{2}+0.25\right) \times \emptyset\right) \times t, L_{g v}$ is the length of gross area subjected to shear and $n_{1}$ is number of bolts in the loading direction. 
Equations (1-4) consider only the shear and tensile failure criteria. The evidence presented in section 5 confirmed that bending and curling should be considered in addition to shear and tensile failure criteria. Therefore, there is a need to device more precise equations that can simulate the real behaviour of the connection and provide reliable estimation to the connection strength. The failure modes which are presented in section 5 can be idealized as shown in Figure 13. The ultimate strength of single shear bolted connection in thin-walled carbon steel can be calculated as follows:

Mode 1: (Figure 13,a)

$P_{u}=P_{u t}+P_{u s}+P_{u b}$

Where,

$P_{u}:$ the ultimate strength of single shear bolted connection in thin-walled carbon steel

$P_{u t}:$ the net tensile fracture strength

$P_{u s}:$ the net shear fracture strength

$P_{u b}:$ the bending fracture strength

$P_{u t}=A_{n t} F_{u}$

$P_{u s}=A_{n s} 0.6 F_{u}$

Kuwamura et al. (cited in [6]) suggested equations (7-9) to calculate the ultimate strength of bending fracture $\left(P_{u b}\right)$.

When, $g \geq 2 e_{o}$

$P_{u b}=n_{t} \frac{4 t e_{o}^{2}}{d} F_{u}, \quad 2 e_{o} \leq d$

$P_{u b}=n_{t} \frac{4 t e_{o}^{2}}{4 e_{o}-d} F_{u}, \quad 2 e_{o}>d$

When, $g<2 e_{o}$

$P_{u b}=n_{t} \frac{t}{2}\left[e_{o}+\left(1+\frac{g+\emptyset}{4 e_{o}}\right) g_{o}\right] F_{u}$

Where,

$A_{n t}:$ net tensile area $=(g-\emptyset) t$

$g$ : bolt gauge distance

$\emptyset$ : hole diameter

$t:$ steel plate thickness

$F_{u}$ : the ultimate tensile strength for steel plate

$A_{n s}:$ net shear area $=(p-\emptyset) t$ 
$p$ : bolt pitch distance

$e_{o}=e_{1}-\frac{\emptyset}{2}$

$g_{o}=g-\varnothing$

$n_{t}:$ total number of bolts

$d$ : bolt diameter

Mode 2: (Figure 13, b)

$P_{u}=P_{u t}+P_{u s}+P_{y b}$

Where, $P_{y b}$ is the bending yielding strength and it can be calculated by replacing the ultimate tensile strength $F_{u}$ by the yielding tensile strength $F_{y}$ in equations (8-10).

Mode 3: (Figure 13, c)

$P_{u}=P_{y t}+P_{y s}+P_{y b}$

$P_{y t}=A_{n t} F_{y}$

$P_{y s}=A_{n s} 0.6 F_{y}$

Where,

$P_{y t}:$ net tensile yielding strength

$P_{y s}$ : net shear yielding strength

Mode 4: Curling mode (Figure 13, d)

$P_{u}=P_{y t}+P_{y b}$

Mode 5: (Figure 13, e)

$P_{u}=b t F_{y}$

Where,

$b$ : width of the steel plate
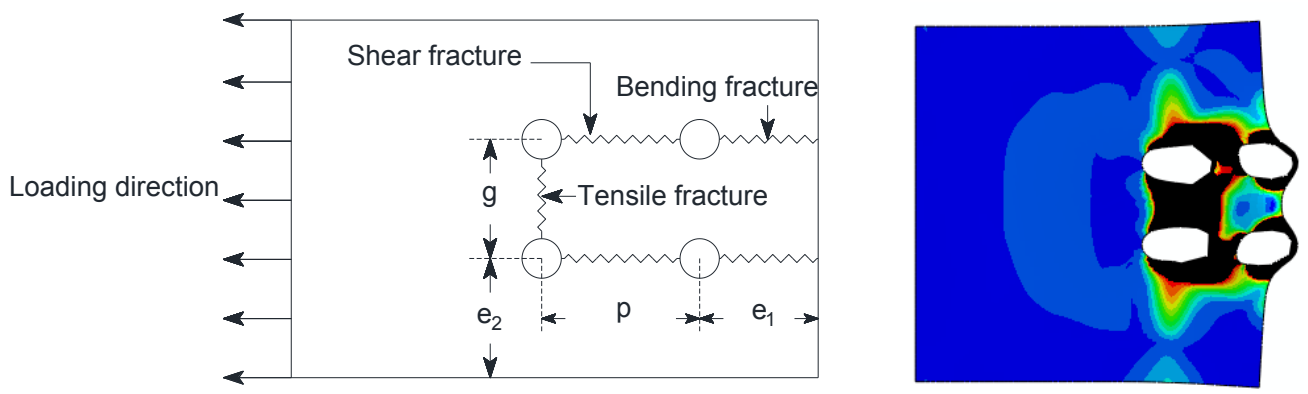

a. Mode 1 

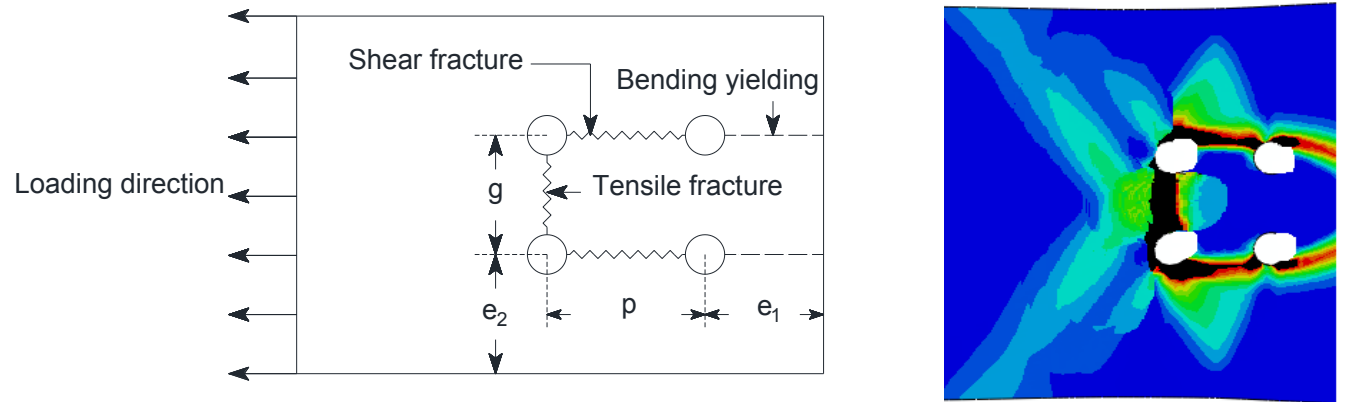

b. Mode 2
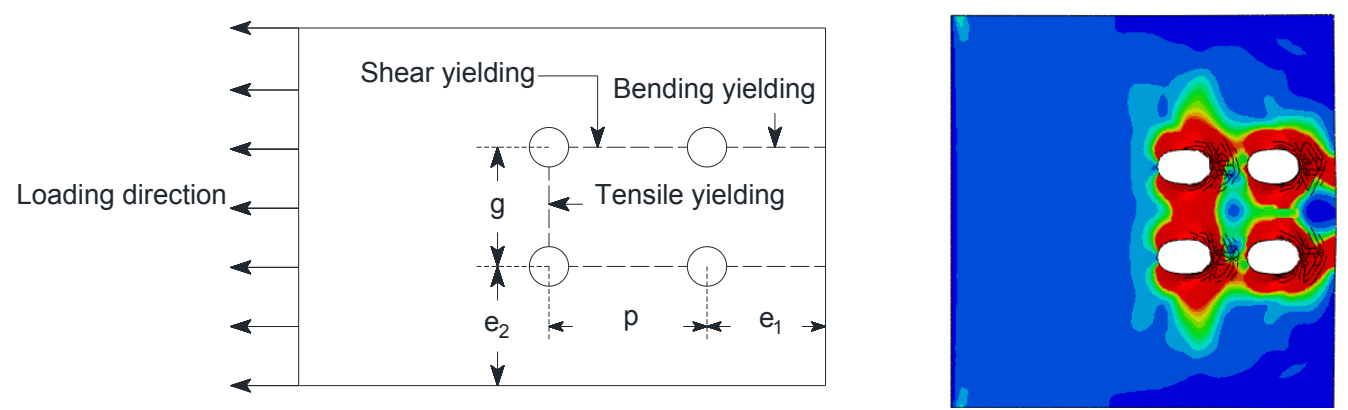

c. Mode 3
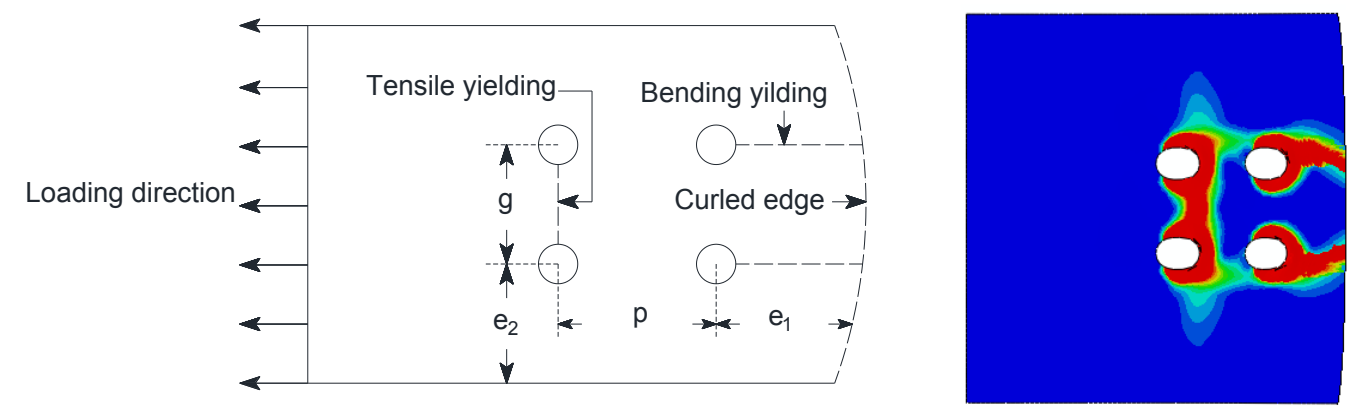

d. Mode 4

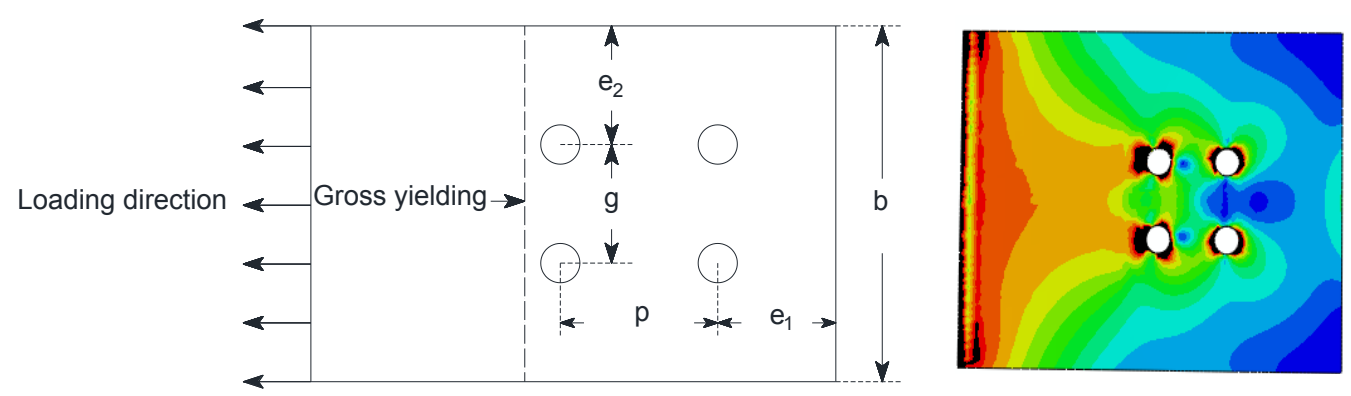

e. Mode 5

Figure 13: Idealized modes of failure

The failure modes for 99 specimens is presented in 
Table 5. The analysis of the results reveals the following recommendations for identifying the failure mode to calculate the ultimate strength of single shear bolted connections in thin-walled carbon steel using the previously defined equations.

Mode $1 \quad e_{1}<18 m m$

Mode $218 m m \leq e_{1}<24 m m$

Mode $324 m m \leq e_{1}<30 m m$

Mode $4 \quad 30 \mathrm{~mm} \leq e_{1}<42 \mathrm{~mm}$, for $t \leq 4 \mathrm{~mm} \quad$ curling mode

Mode $430 \mathrm{~mm} \leq e_{1}<48 \mathrm{~mm}$, for $t>4 \mathrm{~mm} \quad$ curling mode

Mode $542 m m \leq e_{1}$, for $t \leq 4 \mathrm{~mm}$

Mode $548 m m \leq e_{1}$, for $t>4 m m$

Comparisons between the ultimate strength calculated by the proposed models $(\mathrm{Pu} P)$ and the design standards with the experimental ultimate strength of specimens reported by Kim et al. [10] are presented in Table 6 . The comparisons show that the most accurate estimation to the ultimate strength can be obtained using the proposed models. The accuracy of the proposed models is also checked against the FE results and presented in Table 7. The comparison shows that the proposed models can accurately predict the connection strength. However, the proposed models are valid within the range of the investigated parameters: e1 from $18 \mathrm{~mm}$ to $60 \mathrm{~mm}$, plate thickness from $1.5 \mathrm{~mm}$ to $6.5 \mathrm{~mm}$, e2 equals $60 \mathrm{~mm}$, g and $\mathrm{p}$ equal $36 \mathrm{~mm}$. Therefore, there is a need for further experimental and numerical investigations to validate the proposed equations. 
Table 5: Failure modes

\begin{tabular}{llllll}
\hline Specimen & Failure mode & Specimen & Failure mode & Specimen & Failure mode \\
\hline T1.5E12 & Mode 1 & T3.0E48 & Mode 5 & T5.0E30 & Mode 4 \\
T1.5E18 & Mode 2 & T3.0E54 & Mode 5 & T5.0E36 & Mode 4 \\
T1.5E24 & Mode 3 & T3.0E60 & Mode 5 & T5.0E42 & Mode 4 \\
T1.5E30 & Mode 4 & T3.5E12 & Mode 1 & T5.0E48 & Mode 5 \\
T1.5E36 & Mode 4 & T3.5E18 & Mode 2 & T5.0E54 & Mode 5 \\
T1.5E42 & Mode 5 & T3.5E24 & Mode 3 & T5.0E60 & Mode 5 \\
T1.5E48 & Mode 5 & T3.5E30 & Mode 4 & T5.5E12 & Mode 1 \\
T1.5E54 & Mode 5 & T3.5E36 & Mode 4 & T5.5E18 & Mode 2 \\
T1.5E60 & Mode 5 & T3.5E42 & Mode 5 & T5.5E24 & Mode 3 \\
T2.0E12 & Mode 1 & T3.5E48 & Mode 5 & T5.5E30 & Mode 4 \\
T2.0E18 & Mode 2 & T3.5E54 & Mode 5 & T5.5E36 & Mode 4 \\
T2.0E24 & Mode 3 & T3.5E60 & Mode 5 & T5.5E42 & Mode 4 \\
T2.0E30 & Mode 4 & T4.0E12 & Mode 1 & T5.5E48 & Mode 5 \\
T2.0E36 & Mode 4 & T4.0E18 & Mode 2 & T5.5E54 & Mode 5 \\
T2.0E42 & Mode 5 & T4.0E24 & Mode 3 & T5.5E60 & Mode 5 \\
T2.0E48 & Mode 5 & T4.0E30 & Mode 4 & T6.0E12 & Mode 1 \\
& & & &
\end{tabular}




\begin{tabular}{llllll} 
T2.0E54 & Mode 5 & T4.0E36 & Mode 4 & T6.0E18 & Mode 2 \\
T2.0E60 & Mode 5 & T4.0E42 & Mode 4 & T6.0E24 & Mode 3 \\
T2.5E12 & Mode 1 & T4.0E48 & Mode 5 & T6.0E30 & Mode 4 \\
T2.5E18 & Mode 2 & T4.0E54 & Mode 5 & T6.0E36 & Mode 4 \\
T2.5E24 & Mode 3 & T4.0E60 & Mode 5 & T6.0E42 & Mode 4 \\
T2.5E30 & Mode 4 & T4.5E12 & Mode 1 & T6.0E48 & Mode 5 \\
T2.5E36 & Mode 4 & T4.5E18 & Mode 2 & T6.0E54 & Mode 5 \\
T2.5E42 & Mode 5 & T4.5E24 & Mode 3 & T6.0E60 & Mode 5 \\
T2.5E48 & Mode 5 & T4.5E30 & Mode 4 & T6.5E12 & Mode 1 \\
T2.5E54 & Mode 5 & T4.5E36 & Mode 4 & T6.5E18 & Mode 2 \\
T2.5E60 & Mode 5 & T4.5E42 & Mode 4 & T6.5E24 & Mode 3 \\
T3.0E12 & Mode 1 & T4.5E48 & Mode 5 & T6.5E30 & Mode 4 \\
T3.0E18 & Mode 2 & T4.5E54 & Mode 5 & T6.5E36 & Mode 4 \\
T3.0E24 & Mode 3 & T4.5E60 & Mode 5 & T6.5E42 & Mode 4 \\
T3.0E30 & Mode 4 & T5.0E12 & Mode 1 & T6.5E48 & Mode 5 \\
T3.0E36 & Mode 4 & T5.0E18 & Mode 2 & T6.5E54 & Mode 5 \\
T3.0E42 & Mode 5 & T5.0E24 & Mode 3 & T6.5E60 & Mode 5 \\
\hline
\end{tabular}

Table 6: Ultimate strength of experimental [10], proposed models and design standards

\begin{tabular}{|c|c|c|c|c|c|c|c|c|c|}
\hline \multirow{2}{*}{ Specimens } & \multirow{2}{*}{$\begin{array}{c}\text { Exp. } \\
{[10]} \\
P_{\mathrm{u} \text { exp. }} \\
\mathrm{kN}\end{array}$} & \multicolumn{2}{|c|}{ Proposed } & \multicolumn{2}{|c|}{ EC3 } & \multicolumn{4}{|c|}{ AISC and AISI } \\
\hline & & $\mathrm{P}_{\mathrm{u} P \mathrm{NN}}$ & $\begin{array}{c}\mathrm{P}_{\mathrm{u} \text { exp. }} / \\
\mathrm{P}_{\mathrm{u} P}\end{array}$ & $\begin{array}{c}\mathrm{P}_{\mathrm{u}(1)} \mathrm{kN} \\
\text { Eq.(1) }\end{array}$ & $\begin{array}{c}\mathrm{P}_{\mathrm{u} \exp .} / \\
\mathrm{P}_{\mathrm{u}(1)}\end{array}$ & $\begin{array}{c}\mathrm{P}_{\mathrm{u}(2)} \mathrm{kN} \\
\text { Eq.(2) }\end{array}$ & $\mathrm{P}_{\mathrm{u} \text { exp }} / \mathrm{P}_{\mathrm{u}(2)}$ & $\begin{array}{c}\mathrm{P}_{\mathrm{u}(3)} \mathrm{kN} \\
\text { Eq.(3) }\end{array}$ & $\mathrm{P}_{\mathrm{u} \text { exp. }} / \mathrm{P}_{\mathrm{u}}$ \\
\hline $\mathrm{T} 1.5 \mathrm{E} 12$ & 54.68 & 59.20 & 0.92 & 31.95 & 1.71 & 48.72 & 1.12 & 37.24 & 1.47 \\
\hline $\mathrm{T} 1.5 \mathrm{E} 18$ & 60.50 & 65.05 & 0.93 & 35.53 & 1.70 & 52.43 & 1.15 & 41.92 & 1.44 \\
\hline T1.5E24 & 61.28 & 69.70 & 0.88 & 39.10 & 1.57 & 56.15 & 1.09 & 46.61 & 1.31 \\
\hline $\mathrm{T} 1.5 \mathrm{E} 36$ & 66.12 & 75.90 & 0.87 & 46.25 & 1.43 & 63.58 & 1.04 & 55.99 & 1.18 \\
\hline $\mathrm{T} 3.0 \mathrm{E} 24$ & 131.38 & 139.81 & 0.94 & 82.76 & 1.59 & 116.96 & 1.12 & 106.97 & 1.23 \\
\hline $\mathrm{T} 3.0 \mathrm{E} 30$ & 134.52 & 144.88 & 0.93 & 89.93 & 1.50 & 124.41 & 1.08 & 117.73 & 1.14 \\
\hline $\mathrm{T} 3.0 \mathrm{E} 36$ & 142.92 & 152.25 & 0.94 & 97.11 & 1.47 & 131.86 & 1.08 & 128.48 & 1.11 \\
\hline T3.0E48 & 148.63 & 161.46 & 0.92 & 111.45 & 1.33 & 146.76 & 1.01 & 150.00 & 0.99 \\
\hline T3.0E60 & 153.57 & 161.46 & 0.95 & 125.79 & 1.22 & 161.67 & 0.95 & 171.51 & 0.90 \\
\hline T6.0E36 & 201.00 & 195.94 & 1.03 & 126.84 & 1.58 & 171.57 & 1.17 & 172.34 & 1.17 \\
\hline T6.0E48 & 215.54 & 207.79 & 1.04 & 145.30 & 1.48 & 190.75 & 1.13 & 201.20 & 1.07 \\
\hline T6.0E54 & 220.50 & 207.79 & 1.06 & 154.53 & 1.43 & 200.34 & 1.10 & 215.63 & 1.02 \\
\hline T6.0E60 & 222.40 & 207.79 & 1.07 & 163.75 & 1.36 & 209.93 & 1.06 & 230.06 & 0.97 \\
\hline
\end{tabular}


Table 7: Ultimate strength of FE analysis and proposed models

\begin{tabular}{|c|c|c|c|c|c|c|c|c|c|c|c|c|}
\hline \multirow[b]{2}{*}{ Specimen } & \multirow[b]{2}{*}{$\begin{array}{c}\text { Failure } \\
\text { mode }\end{array}$} & \multirow[b]{2}{*}{$\begin{array}{l}P_{\mathrm{u} F E} \\
(\mathrm{kN})\end{array}$} & \multirow[b]{2}{*}{$\begin{array}{c}P_{n} P \\
(k N)\end{array}$} & \multirow[b]{2}{*}{$\begin{array}{c}\mathrm{P}_{\mathrm{uFE}} / \\
\mathrm{P}_{\mathrm{u} \mathrm{P}}\end{array}$} & \multicolumn{2}{|c|}{ EC3 } & \multicolumn{4}{|c|}{ AISC and AISI } & \multicolumn{2}{|c|}{ Teh et al. [22] } \\
\hline & & & & & $\begin{array}{c}\mathrm{P}_{\mathrm{u} 1}(\mathrm{kN}) \\
\text { Eq.1 }\end{array}$ & $\begin{array}{c}\mathrm{P}_{\mathrm{u} \text { FE }} / \\
\mathrm{P}_{\mathrm{u} 1}\end{array}$ & $\begin{array}{l}\mathrm{P}_{\mathrm{u} 2} \mathrm{kN} \\
\text { Eq. (2) }\end{array}$ & $\begin{array}{c}\mathrm{P}_{\mathrm{u} \text { exp. }} / \\
\mathrm{P}_{\mathrm{u} 2}\end{array}$ & $\begin{array}{l}\mathrm{P}_{\mathrm{u} 3} \mathrm{kN} \\
\mathrm{Eq} .(3)\end{array}$ & $\begin{array}{c}\mathrm{P}_{\mathrm{u} \text { exp. }} / \\
\mathrm{P}_{\mathrm{u} 3}\end{array}$ & $\begin{array}{c}\mathrm{P}_{\mathrm{u} 4}(\mathrm{kN}) \\
\text { Eq.4 }\end{array}$ & $\begin{array}{c}\mathrm{P}_{\mathrm{u} \text { FE }} / \\
\mathrm{P}_{\mathrm{u} 4}\end{array}$ \\
\hline $\mathrm{T} 1.5 \mathrm{E} 12$ & Mode 1 & 62.582 & 65.621 & 0.954 & 31.954 & 0.511 & 48.719 & 0.778 & 37.237 & 0.595 & 44.703 & 0.714 \\
\hline $\mathrm{T} 1.5 \mathrm{E} 18$ & Mode 2 & 67.525 & 67.397 & 1.002 & 35.529 & 0.526 & 52.435 & 0.777 & 41.924 & 0.621 & 53.449 & 0.792 \\
\hline $\mathrm{T} 1.5 \mathrm{E} 24$ & Mode 3 & 69.087 & 71.827 & 0.962 & 39.104 & 0.566 & 56.150 & 0.813 & 46.612 & 0.675 & 57.164 & 0.827 \\
\hline $\mathrm{T} 1.5 \mathrm{E} 30$ & Mode 4 & 71.622 & 74.304 & 0.964 & 42.679 & 0.596 & 59.865 & 0.836 & 51.299 & 0.716 & 60.879 & 0.850 \\
\hline $\mathrm{T} 1.5 \mathrm{E} 36$ & Mode 4 & 73.102 & 78.019 & 0.937 & 46.254 & 0.633 & 63.580 & 0.870 & 55.986 & 0.766 & 64.594 & 0.884 \\
\hline $\mathrm{T} 1.5 \mathrm{E} 42$ & Mode 5 & 77.121 & 80.496 & 0.958 & 49.829 & 0.646 & 67.295 & 0.873 & 60.673 & 0.787 & 68.310 & 0.886 \\
\hline $\mathrm{T} 1.5 \mathrm{E} 48$ & Mode 5 & 77.542 & 80.496 & 0.963 & 53.404 & 0.689 & 71.011 & 0.916 & 65.360 & 0.843 & 72.025 & 0.929 \\
\hline $\mathrm{T} 1.5 \mathrm{E} 54$ & Mode 5 & 77.769 & 80.496 & 0.966 & 56.979 & 0.733 & 74.726 & 0.961 & 70.048 & 0.901 & 75.740 & 0.974 \\
\hline $\mathrm{T} 1.5 \mathrm{E} 60$ & Mode 5 & 77.917 & 80.496 & 0.968 & 60.554 & 0.777 & 78.441 & 1.007 & 74.735 & 0.959 & 79.455 & 1.020 \\
\hline $\mathrm{T} 2.0 \mathrm{E} 12$ & Mode 1 & 88.103 & 87.494 & 1.007 & 42.605 & 0.484 & 64.959 & 0.737 & 49.650 & 0.564 & 66.311 & 0.753 \\
\hline $\mathrm{T} 2.0 \mathrm{E} 18$ & Mode 2 & 88.462 & 89.862 & 0.984 & 47.372 & 0.536 & 69.913 & 0.790 & 55.899 & 0.632 & 71.265 & 0.806 \\
\hline $\mathrm{T} 2.0 \mathrm{E} 24$ & Mode 3 & 90.893 & 95.770 & 0.949 & 52.139 & 0.574 & 74.866 & 0.824 & 62.149 & 0.684 & 76.219 & 0.839 \\
\hline $\mathrm{T} 2.0 \mathrm{E} 30$ & Mode 4 & 92.561 & 99.072 & 0.934 & 56.905 & 0.615 & 79.820 & 0.862 & 68.398 & 0.739 & 81.172 & 0.877 \\
\hline $\mathrm{T} 2.0 \mathrm{E} 36$ & Mode 4 & 98.987 & 104.026 & 0.952 & 61.672 & 0.623 & 84.774 & 0.856 & 74.648 & 0.754 & 86.126 & 0.870 \\
\hline $\mathrm{T} 2.0 \mathrm{E} 42$ & Mode 5 & 103.124 & 107.328 & 0.961 & 66.438 & 0.644 & 89.727 & 0.870 & 80.898 & 0.784 & 91.079 & 0.883 \\
\hline $\mathrm{T} 2.0 \mathrm{E} 48$ & Mode 5 & 103.465 & 107.328 & 0.964 & 71.205 & 0.688 & 94.681 & 0.915 & 87.147 & 0.842 & 96.033 & 0.928 \\
\hline $\mathrm{T} 2.0 \mathrm{E} 54$ & Mode 5 & 103.566 & 107.328 & 0.965 & 75.972 & 0.734 & 99.634 & 0.962 & 93.397 & 0.902 & 100.987 & 0.975 \\
\hline $\mathrm{T} 2.0 \mathrm{E} 60$ & Mode 5 & 103.723 & 107.328 & 0.966 & 80.738 & 0.778 & 104.588 & 1.008 & 99.646 & 0.961 & 105.940 & 1.021 \\
\hline $\mathrm{T} 2.5 \mathrm{E} 12$ & Mode 1 & 105.931 & 109.368 & 0.969 & 53.257 & 0.503 & 81.199 & 0.767 & 62.062 & 0.586 & 82.889 & 0.782 \\
\hline $\mathrm{T} 2.5 \mathrm{E} 18$ & Mode 2 & 109.704 & 112.328 & 0.977 & 59.215 & 0.540 & 87.391 & 0.797 & 69.874 & 0.637 & 89.081 & 0.812 \\
\hline $\mathrm{T} 2.5 \mathrm{E} 24$ & Mode 3 & 114.627 & 119.712 & 0.958 & 65.173 & 0.569 & 93.583 & 0.816 & 77.686 & 0.678 & 95.273 & 0.831 \\
\hline $\mathrm{T} 2.5 \mathrm{E} 30$ & Mode 4 & 119.359 & 123.840 & 0.964 & 71.131 & 0.596 & 99.775 & 0.836 & 85.498 & 0.716 & 101.465 & 0.850 \\
\hline
\end{tabular}




\begin{tabular}{|c|c|c|c|c|c|c|c|c|c|c|c|c|}
\hline \multirow[b]{2}{*}{ Specimen } & \multirow[b]{2}{*}{$\begin{array}{l}\text { Failure } \\
\text { mode }\end{array}$} & \multirow[b]{2}{*}{$\begin{array}{l}\mathrm{P}_{\mathrm{uFE}} \\
(\mathrm{kN})\end{array}$} & \multirow[b]{2}{*}{$\begin{array}{c}\mathrm{P}_{\mathrm{nP}} \\
(\mathrm{kN})\end{array}$} & \multirow[b]{2}{*}{$\begin{array}{c}\mathrm{P}_{\mathrm{uFE}} / \\
\mathrm{P}_{\mathrm{u} \mathrm{P}}\end{array}$} & \multicolumn{2}{|c|}{$\mathrm{EC} 3$} & \multicolumn{4}{|c|}{ AISC and AISI } & \multicolumn{2}{|c|}{ Teh et al. [22] } \\
\hline & & & & & $\begin{array}{c}\mathrm{P}_{\mathrm{u} 1}(\mathrm{kN}) \\
\text { Eq.1 }\end{array}$ & $\begin{array}{c}\mathrm{P}_{\mathrm{uFE}} / \\
\mathrm{P}_{\mathrm{u} 1} \\
\end{array}$ & $\begin{array}{l}\mathrm{P}_{\mathrm{u} 2} \mathrm{kN} \\
\text { Eq. (2) } \\
\end{array}$ & $\begin{array}{c}\mathrm{P}_{\mathrm{u} \text { exp }} / \\
\mathrm{P}_{\mathrm{u} 2} \\
\end{array}$ & $\begin{array}{l}\mathrm{P}_{\mathrm{u} 3} \mathrm{kN} \\
\text { Eq. (3) } \\
\end{array}$ & $\begin{array}{c}\mathrm{P}_{\mathrm{u} \text { exp. }} / \\
\mathrm{P}_{\mathrm{u} 3} \\
\end{array}$ & $\begin{array}{c}\mathrm{P}_{\mathrm{u} 4}(\mathrm{kN}) \\
\text { Eq.4 }\end{array}$ & $\begin{array}{c}\mathrm{P}_{\mathrm{uFE}} / \\
\mathrm{P}_{\mathrm{u} 4} \\
\end{array}$ \\
\hline T2.5E36 & Mode 4 & 123.767 & 130.032 & 0.952 & 77.090 & 0.623 & 105.967 & 0.856 & 93.310 & 0.754 & 107.657 & 0.870 \\
\hline $\mathrm{T} 2.5 \mathrm{E} 42$ & Mode 5 & 130.418 & 134.160 & 0.972 & 83.048 & 0.637 & 112.159 & 0.860 & 101.122 & 0.775 & 13.849 & 0.873 \\
\hline $\mathrm{T} 2.5 \mathrm{E} 48$ & Mode 5 & 131.275 & 134.160 & 0.978 & 89.006 & 0.678 & 118.351 & 0.902 & 108.934 & 0.830 & 120.041 & 0.914 \\
\hline $\mathrm{T} 2.5 \mathrm{E} 54$ & Mode 5 & 132.502 & 134.160 & 0.988 & 94.964 & 0.717 & 124.543 & 0.940 & 116.746 & 0.881 & 126.233 & 0.953 \\
\hline $\mathrm{T} 2.5 \mathrm{E} 60$ & Mode 5 & 133.012 & 134.160 & 0.991 & 100.923 & 0.759 & 130.735 & 0.983 & 124.558 & 0.936 & 132.425 & 0.996 \\
\hline $\mathrm{T} 3.0 \mathrm{E} 12$ & Mode 1 & 133.678 & 131.242 & 1.019 & 63.908 & 0.478 & 97.439 & 0.729 & 74.474 & 0.557 & 99.467 & 0.744 \\
\hline T3.0E18 & Mode 2 & 133.839 & 134.794 & 0.993 & 71.058 & 0.531 & 104.869 & 0.784 & 83.849 & 0.626 & 106.898 & 0.799 \\
\hline T3.0E24 & Mode 3 & 138.666 & 143.654 & 0.965 & 78.208 & 0.564 & 112.300 & 0.810 & 93.223 & 0.672 & 28 & 0.824 \\
\hline $\mathrm{T} 3.0 \mathrm{E} 30$ & Mode 4 & 143.625 & 148.608 & 0.966 & 85.358 & 0.594 & 119.730 & 0.834 & 102.598 & 0.714 & 121.758 & 0.848 \\
\hline T3.0E36 & Mode 4 & 152.014 & 156.038 & 0.974 & 92.508 & 0.609 & 127.160 & 0.837 & 111.972 & 0.737 & 129.189 & 0.850 \\
\hline T3.0E42 & Mode 5 & 155.325 & 160.992 & 0.965 & 99.658 & 0.642 & 134.591 & 0.867 & 121.346 & 0.781 & 136.619 & 0.880 \\
\hline T3.0E48 & Mode 5 & 155.655 & 156.780 & 0.993 & 106.807 & 0.686 & 142.021 & 0.912 & 130.721 & 0.840 & 144.050 & 0.925 \\
\hline T3.0E54 & Mode 5 & 155.931 & 156.780 & 0.995 & 113.957 & 0.731 & 149.452 & 0.958 & 140.095 & 0.898 & 151.480 & 0.971 \\
\hline T3.0E60 & Mode 5 & 156.142 & 156.780 & 0.996 & 121.107 & 0.776 & 156.882 & 1.005 & 149.470 & 0.957 & 158.910 & 1.018 \\
\hline $\mathrm{T} 3.5 \mathrm{E} 12$ & Mode 1 & 150.663 & 153.115 & 0.984 & 74.559 & 0.495 & 113.679 & 0.755 & 86.887 & 0.577 & 116.045 & 0.770 \\
\hline T3.5E18 & Mode 2 & 156.717 & 155.243 & 1.009 & 82.901 & 0.529 & 122.347 & 0.781 & 97.824 & 0.624 & 124.714 & 0.796 \\
\hline T3.5E24 & Mode 3 & 161.478 & 167.597 & 0.963 & 91.243 & 0.565 & 131.016 & 0.811 & 108.760 & 0.674 & 133.383 & 0.826 \\
\hline T3.5E30 & Mode 4 & 164.612 & 173.376 & 0.949 & 99.584 & 0.605 & 139.685 & 0.849 & 119.697 & 0.727 & 142.051 & 0.863 \\
\hline T3.5E36 & Mode 4 & 171.630 & 182.045 & 0.943 & 107.926 & 0.629 & 148.354 & 0.864 & 130.634 & 0.761 & 150.720 & 0.878 \\
\hline T3.5E42 & Mode 5 & 182.592 & 187.824 & 0.972 & 116.267 & 0.637 & 157.023 & 0.860 & 141.571 & 0.775 & 159.389 & 0.873 \\
\hline T3.5E48 & Mode 5 & 182.503 & 187.824 & 0.972 & 124.609 & 0.683 & 165.691 & 0.908 & 152.508 & 0.836 & 168.058 & 0.921 \\
\hline T3.5E54 & Mode 5 & 182.487 & 187.824 & 0.972 & 132.950 & 0.729 & 174.360 & 0.955 & 163.444 & 0.896 & 176.727 & 0.968 \\
\hline T3.5E60 & Mode 5 & 183.517 & 187.824 & 0.977 & 141.292 & 0.770 & 183.029 & 0.997 & 174.381 & 0.950 & 185.395 & 1.010 \\
\hline $\mathrm{T} 4.0 \mathrm{E} 12$ & Mode 1 & 178.056 & 174.989 & 1.018 & 85.211 & 0.479 & 129.918 & 0.730 & 99.299 & 0.558 & 132.623 & 0.745 \\
\hline $\mathrm{T} 4.0 \mathrm{E} 18$ & Mode 2 & 178.154 & 177.165 & 1.006 & 94.744 & 0.532 & 139.826 & 0.785 & 111.798 & 0.628 & 142.530 & 0.800 \\
\hline $\mathrm{T} 4.0 \mathrm{E} 24$ & Mode 3 & 185.421 & 191.539 & 0.968 & 104.277 & 0.562 & 149.733 & 0.808 & 124.298 & 0.670 & 152.437 & 0.822 \\
\hline $\mathrm{T} 4.0 \mathrm{E} 30$ & Mode 4 & 189.222 & 198.144 & 0.955 & 113.810 & 0.601 & 159.640 & 0.844 & 136.797 & 0.723 & 162.345 & 0.858 \\
\hline T4.0E36 & Mode 4 & 198.954 & 208.051 & 0.956 & 123.344 & 0.620 & 169.547 & 0.852 & 149.296 & 0.750 & 172.252 & 0.866 \\
\hline $\mathrm{T} 4.0 \mathrm{E} 42$ & Mode 4 & 212.106 & 220.160 & 0.963 & 132.877 & 0.626 & 179.454 & 0.846 & 161.795 & 0.763 & 182.159 & 0.859 \\
\hline $\mathrm{T} 4.0 \mathrm{E} 48$ & Mode 5 & 208.235 & 214.656 & 0.970 & 142.410 & 0.684 & 189.362 & 0.909 & 174.294 & 0.837 & 192.066 & 0.922 \\
\hline T4.0E54 & Mode 5 & 208.468 & 214.656 & 0.971 & 151.943 & 0.729 & 199.269 & 0.956 & 186.794 & 0.896 & 201.973 & 0.969 \\
\hline T4.0E60 & Mode 5 & 208.956 & 214.656 & 0.973 & 161.476 & 0.773 & 209.176 & 1.001 & 199.293 & 0.954 & 211.881 & 1.014 \\
\hline $\mathrm{T} 4.5 \mathrm{E} 12$ & Mode 1 & 194.538 & 196.862 & 0.988 & 95.862 & 0.493 & 146.158 & 0.751 & 111.712 & 0.574 & 149.201 & 0.767 \\
\hline T4.5E18 & Mode 2 & 201.736 & 202.190 & 0.998 & 106.587 & 0.528 & 157.304 & 0.780 & 125.773 & 0.623 & 160.346 & 0.795 \\
\hline $\mathrm{T} 4.5 \mathrm{E} 24$ & Mode 3 & 208.172 & 215.482 & 0.966 & 117.312 & 0.564 & 168.449 & 0.809 & 139.835 & 0.672 & 171.492 & 0.824 \\
\hline $\mathrm{T} 4.5 \mathrm{E} 30$ & Mode 4 & 215.723 & 222.912 & 0.968 & 128.037 & 0.594 & 179.595 & 0.833 & 153.896 & 0.713 & 182.638 & 0.847 \\
\hline T4.5E36 & Mode 4 & 222.354 & 234.058 & 0.950 & 138.762 & 0.624 & 190.741 & 0.858 & 167.958 & 0.755 & 193.783 & 0.872 \\
\hline $\mathrm{T} 4.5 \mathrm{E} 42$ & Mode 4 & 230.789 & 247.680 & 0.932 & 149.486 & 0.648 & 201.886 & 0.875 & 182.020 & 0.789 & 204.929 & 0.888 \\
\hline $\mathrm{T} 4.5 \mathrm{E} 48$ & Mode 5 & 239.906 & 241.488 & 0.993 & 160.211 & 0.668 & 213.032 & 0.888 & 196.081 & 0.817 & 216.074 & 0.901 \\
\hline T4.5E54 & Mode 5 & 240.059 & 241.488 & 0.994 & 170.936 & 0.712 & 224.177 & 0.934 & 210.143 & 0.875 & 227.220 & 0.947 \\
\hline T4.5E60 & Mode 5 & 241.308 & 241.488 & 0.999 & 181.661 & 0.753 & 235.323 & 0.975 & 224.204 & 0.929 & 238.366 & 0.988 \\
\hline T5.0E12 & Mode 1 & & & 1.017 & 106.513 & 0.479 & 162.398 & 0.730 & 124.124 & 0.558 & 165.779 & 0.746 \\
\hline T5.0E18 & Mode 2 & 223.964 & 224.656 & 0.997 & 118.430 & 0.529 & 174.782 & 0.780 & 139.748 & 0.624 & 178.163 & 0.795 \\
\hline T5.0E24 & Mode 3 & 231.582 & 239.424 & 0.967 & 130.346 & 0.563 & 187.166 & 0.808 & 155.372 & 0.671 & 190.547 & 0.823 \\
\hline T5.0E30 & Mode 4 & 238.687 & & 0.964 & 142.263 & 6 & 199.550 & 0.836 & 170.996 & 0.716 & 202.931 & 0.850 \\
\hline T5.0E36 & Mode 4 & 248.729 & 260.064 & 0.956 & 154.179 & 0.620 & 211.934 & 0.852 & 186.620 & 0.750 & 215.315 & 0.866 \\
\hline $\mathrm{T} 5.0 \mathrm{E} 42$ & Mode 4 & 257.798 & 275.200 & 0.937 & 166.096 & 0.644 & 224.318 & 0.870 & 202.244 & 0.785 & 227.699 & 0.883 \\
\hline T5.0E48 & & 260.243 & & 0.970 & 178.012 & 0.684 & 236.702 & 0.910 & 217.868 & 0.837 & 240.083 & 0.923 \\
\hline T5.0E54 & Mode 5 & 260.685 & 268.320 & 0.972 & 189.929 & 0.729 & 249.086 & 0.956 & 233.492 & 0.896 & 252.467 & 0.968 \\
\hline T5.0E60 & Mode 5 & 261.015 & 268.320 & 0.973 & 201.845 & 0.773 & 261.470 & 1.002 & 249.116 & 0.954 & 264.851 & 1.015 \\
\hline T5.5E12 & Mode 1 & 240.525 & 240.610 & 1.000 & 117 & 0.487 & 178.638 & 0.743 & 136.536 & 0.568 & 182.357 & 0.758 \\
\hline T5.5E18 & Mode 2 & 249.299 & 247.122 & 1.009 & 130.273 & 0.523 & 192.260 & 0.771 & 153.723 & 0.617 & 195.979 & 0.786 \\
\hline T5.5E24 & Mode 3 & 255.706 & 263.366 & 0.971 & 143.381 & 0.561 & 205.883 & 0.805 & 170.909 & 0.668 & 209.601 & 0.820 \\
\hline T5.5E30 & Mode 4 & 261.189 & 272.448 & 0.959 & 156.489 & 0.599 & 219.505 & 0.840 & 188.096 & 0.720 & 223.224 & 0.855 \\
\hline T5.5E36 & Mode 4 & 271.051 & 286.070 & 0.947 & 169.597 & 0.626 & 233.127 & 0.860 & 205.282 & 0.757 & 236.846 & 0.874 \\
\hline T5.5E42 & Mode 4 & 279.629 & 302.720 & 0.924 & 182.706 & 0.653 & 246.750 & 0.882 & 222.468 & 0.796 & 250.469 & 0.896 \\
\hline T5.5E48 & Mode 5 & 290.128 & 295.152 & 0.983 & 195.814 & 0.675 & 260.372 & 0.897 & 239.655 & 0.826 & 264.091 & 0.910 \\
\hline T5.5E54 & Mode 5 & 293.291 & 295.152 & 0.994 & 208.922 & 0.712 & 273.995 & 0.934 & 256.841 & 0.876 & 277.713 & 0.947 \\
\hline T5.5E60 & Mode 5 & 293.713 & 295.152 & 0.995 & 222.030 & 0.756 & 287.617 & 0.979 & 274.028 & 0.933 & 291.336 & 0.992 \\
\hline
\end{tabular}




\begin{tabular}{|c|c|c|c|c|c|c|c|c|c|c|c|c|}
\hline \multirow[b]{2}{*}{ Specimen } & \multirow[b]{2}{*}{$\begin{array}{c}\text { Failure } \\
\text { mode }\end{array}$} & \multirow[b]{2}{*}{$\begin{array}{l}P_{\mathrm{u} F E} \\
(\mathrm{kN})\end{array}$} & \multirow[b]{2}{*}{$\begin{array}{c}P_{n ~ P} \\
(k N)\end{array}$} & \multirow[b]{2}{*}{$\begin{array}{c}\mathrm{P}_{\mathrm{uFE}} / \\
\mathrm{P}_{\mathrm{u} \mathrm{P}}\end{array}$} & \multicolumn{2}{|c|}{ EC3 } & \multicolumn{4}{|c|}{ AISC and AISI } & \multicolumn{2}{|c|}{ Teh et al. [22] } \\
\hline & & & & & $\begin{array}{c}\mathrm{P}_{\mathrm{u} 1}(\mathrm{kN}) \\
\text { Eq. } 1\end{array}$ & $\begin{array}{c}\mathrm{P}_{\mathrm{uFE}} / \\
\mathrm{P}_{\mathrm{u} 1}\end{array}$ & $\begin{array}{l}\mathrm{P}_{\mathrm{u} 2} \mathrm{kN} \\
\text { Eq. (2) }\end{array}$ & $\begin{array}{c}\mathrm{P}_{\mathrm{u} \text { exp. }} / \\
\mathrm{P}_{\mathrm{u} 2}\end{array}$ & $\begin{array}{l}\mathrm{P}_{\mathrm{u} 3} \mathrm{kN} \\
\mathrm{Eq} .(3)\end{array}$ & $\begin{array}{c}\mathrm{P}_{\mathrm{u} \text { exp. }} / \\
\mathrm{P}_{\mathrm{u} 3}\end{array}$ & $\begin{array}{c}\mathrm{P}_{\mathrm{u} 4}(\mathrm{kN}) \\
\text { Eq.4 }\end{array}$ & $\begin{array}{c}\mathrm{P}_{\mathrm{uFE}} / \\
\mathrm{P}_{\mathrm{u} 4}\end{array}$ \\
\hline T6.0E12 & Mode 1 & 266.351 & 262.483 & 1.015 & 127.816 & 0.480 & 194.878 & 0.732 & 148.949 & 0.559 & 198.934 & 0.747 \\
\hline $\mathrm{T} 6.0 \mathrm{E} 18$ & Mode 2 & 267.569 & 269.587 & 0.993 & 142.116 & 0.531 & 209.738 & 0.784 & 167.698 & 0.627 & 213.795 & 0.799 \\
\hline T6.0E24 & Mode 3 & 275.842 & 287.309 & 0.960 & 156.416 & 0.567 & 224.599 & 0.814 & 186.446 & 0.676 & 228.656 & 0.829 \\
\hline $\mathrm{T} 6.0 \mathrm{E} 30$ & Mode 4 & 285.876 & 297.216 & 0.962 & 170.716 & 0.597 & 239.460 & 0.838 & 205.195 & 0.718 & 243.517 & 0.852 \\
\hline $\mathrm{T} 6.0 \mathrm{E} 36$ & Mode 4 & 298.658 & 312.077 & 0.957 & 185.015 & 0.619 & 254.321 & 0.852 & 223.944 & 0.750 & 258.378 & 0.865 \\
\hline $\mathrm{T} 6.0 \mathrm{E} 42$ & Mode 4 & 315.586 & 330.240 & 0.956 & 199.315 & 0.632 & 269.182 & 0.853 & 242.693 & 0.769 & 273.238 & 0.866 \\
\hline $\mathrm{T} 6.0 \mathrm{E} 48$ & Mode 5 & 314.651 & 321.984 & 0.977 & 213.615 & 0.679 & 284.042 & 0.903 & 261.442 & 0.831 & 288.099 & 0.916 \\
\hline T6.0E54 & Mode 5 & 314.782 & 321.984 & 0.978 & 227.915 & 0.724 & 298.903 & 0.950 & 280.190 & 0.890 & 302.960 & 0.962 \\
\hline T6.0E60 & Mode 5 & 314.928 & 321.984 & 0.978 & 242.215 & 0.769 & 313.764 & 0.996 & 298.939 & 0.949 & 317.821 & 1.009 \\
\hline T6.5E12 & Mode 1 & 280.291 & 284.357 & 0.986 & 138.467 & 0.494 & 211.117 & 0.753 & 161.361 & 0.576 & 215.512 & 0.769 \\
\hline T6.5E18 & Mode 2 & 291.683 & 292.053 & 0.999 & 153.959 & 0.528 & 227.217 & 0.779 & 181.672 & 0.623 & 231.611 & 0.794 \\
\hline T6.5E24 & Mode 3 & 303.239 & 311.251 & 0.974 & 169.450 & 0.559 & 243.316 & 0.802 & 201.984 & 0.666 & 247.711 & 0.817 \\
\hline T6.5E30 & Mode 4 & 313.737 & 321.984 & 0.974 & 184.942 & 0.589 & 259.415 & 0.827 & 222.295 & 0.709 & 263.810 & 0.841 \\
\hline T6.5E36 & Mode 4 & 324.402 & 338.083 & 0.960 & 200.433 & 0.618 & 275.514 & 0.849 & 242.606 & 0.748 & 279.909 & 0.863 \\
\hline $\mathrm{T} 6.5 \mathrm{E} 42$ & Mode 4 & 333.942 & 357.760 & 0.933 & 215.925 & 0.647 & 291.613 & 0.873 & 262.917 & 0.787 & 296.008 & 0.886 \\
\hline T6.5E48 & Mode 5 & 341.808 & 348.816 & 0.980 & 231.416 & 0.677 & 307.713 & 0.900 & 283.228 & 0.829 & 312.107 & 0.913 \\
\hline T6.5E54 & Mode 5 & 346.094 & 348.816 & 0.992 & 246.908 & 0.713 & 323.812 & 0.936 & 303.540 & 0.877 & 328.207 & 0.948 \\
\hline T6.5E60 & Mode 5 & $\frac{348.047}{n}$ & 348.816 & $\frac{0.998}{0.97}$ & 262.399 & $\frac{0.754}{0 .}-\overline{62}$ & 339.911 & -0.977 & 323.851 & $-\frac{0.930}{0.75}$ & 344.306 & $\frac{0.989}{0.87}$ \\
\hline & Standard & eviation & & 0.02 & & 0.09 & & 0.08 & & 0.12 & & 0.08 \\
\hline & efficient & f variation & & 0.02 & & 0.14 & & 0.09 & & 0.15 & & 0.09 \\
\hline
\end{tabular}

\section{SUMMARY AND CONCLUSIONS}

The ultimate strength and the failure sequence of bolted single-shear connections in thin-walled carbon steel was investigated using finite element analysis. Parametric study was performed to evaluate the effect of the influential parameters on the connection behaviour. The output of the finite element analysis was used to propose analytical models to estimate the ultimate strength of the connections. The proposed models are based on three failure criteria: tensile, shear and bending along the end distance in addition to the curling. The models were validated against experimental [10] data and they provided excellent prediction of the connection ultimate strength. The design standards for steel structures such as EC3, AISI and AISC tend to underestimate the connection strength comparing with the experimental data [10]. However, the proposed models provide more accurate estimation of the connection strength. The strain distribution of the steel plate was investigated and revealed five failure modes. It is recommended to limit the maximum end distance to $50 \mathrm{~mm}$ as no strength improvement can be obtained beyond this limit. The curling displacement affects the patterns of yielding and controls the connection strength and is considered as sign of failure only when it reaches $0.5 \mathrm{~mm}$ before the ultimate strength of the connection is reached. The existence of curling could reduce the connection strength by $12 \%$ and results in sharper drop in the strength after the ultimate strength. 


\section{REFERENCES}

1. Kulak, G.L., J.W. Fisher, and J.H. Struik, Guide to Design Criteria for Bolted and Riveted Joints Second Edition. 2001.

2. Winter, G., Tests on bolted connections in light gage steel. Journal of the Structural Division, 1956. 82(2): p. 1-25.

3. Kim, H.J. and J.A. Yura, The effect of ultimate-to-yield ratio on the bearing strength of bolted connections. Journal of Constructional Steel Research, 1999. 49(3): p. 255-269.

4. Topkaya, C., A finite element parametric study on block shear failure of steel tension members. Journal of Constructional Steel Research, 2004. 60(11): p. 1615-1635.

5. Kim and Kuwamura, Finite Element Modeling of Bolted Connections in Thin-Walled Stainless Steel Plates under Static Shear. Thin-Walled Structures, 2007. 45(4): p. 407-421.

6. Kim, T.S., H. Kuwamura, and T.J. Cho, A Parametric Study on Ultimate Strength of Single Shear Bolted Connections with Curling. Thin-Walled Structures, 2008. 46(1): p. 38-53.

7. Teh, L.H. and D.D.A. Clements, Block Shear Capacity of Bolted Connections in Cold-Reduced Steel Sheets. Journal of Structural Engineering, 2012. 138(4): p. 459-467.

8. Clements, D.D.A. and L.H. Teh, Active Shear Planes of Bolted Connections Failing in Block Shear. Journal of Structural Engineering, 2013. 139(3): p. 320-327.

9. Kim, T. and J. Lim, Ultimate strength of single shear two-bolted connections with austenitic stainless steel. International Journal of Steel Structures, 2013. 13(1): p. 117-128.

10. Kim, T., J. Yoo, and C.W. Roeder, Experimental Investigation on Strength and Curling Influence of Bolted Connections in Thin-Walled Carbon Steel. Thin-Walled Structures, 2015. 91(Supplement C): p. 1-12.

11. Kim, T., M. Kim, and T. Cho, Parametric Study on Ultimate Strength of Four-bolted Connections with Cold-formed Carbon Steel. International Journal of Steel Structures, 2018. 18(1): p. 265-280.

12. Repair, H. Flowdrill. 2019 2019]]; Available from: http://m.helprepair.info/construction and infrastructure/light steel thinwalled structures Istc.

13. Dassault, Abaqus v. 6.13-2 [Software], in Dassault Systèmes Simulia Corp. 2013, Providence, RI: Dassault Systèmes Simulia Corp.

14. Chung, K.F. and K.H. Ip, Finite element modeling of bolted connections between cold-formed steel strips and hot rolled steel plates under static shear loading. Engineering Structures, 2000. 22(10): p. 1271-1284.

15. Mahmood, M., W. Tizani, and C. Sansour, Effect of Tube Thickness on the Face Bending for BlindBolted Connection to Concrete Filled Tubular Structures. International Journal of Civil, Architectural, Structural and Construction Engineering, 2014. 8(9): p. 904-910.

16. Epstein, H.I. and M.J. McGinnis, Finite element modeling of block shear in structural tees. Computers \& Structures, 2000. 77(5): p. 571-582.

17. Kim, T.S. and H. Kuwamura, Numerical Investigation on Strength Design and Curling Effect of Mechanically Fastened Joints In Cold-Formed Austenitic Stainless Steel. Materials \& Design, 2011. 32(7): p. 3942-3956.

18. Lecce, M. and K.J.R. Rasmussen, Nonlinear Flange Curling in Wide Flange Sections. Journal of Constructional Steel Research, 2008. 64(7): p. 779-784.

19. CEN, Eurocode 3: Design of steel structures - Part 1-3-General Rules: Supplementary rules for cold formed thin gauge members and sheeting., in EN 1996-1-3. 2005, CEN.

20. CEN, Eurocode 3: Design of steel structures - Part 1-8: Design of joints, in EN 1993-1-8. 2005, CEN.

21. (AISI), North American specification for the design of cold-formed steel structural members, in AISI S100-12. 2012, American Iron and Steel Institute: Washington D.C.,USA.

22. (AISC), Steel construction manual. 2011, American Institute of Steel Construction: USA.

23. Teh, L.H. and D. Clements, Block Shear Capacity of Bolted Connections in Cold-Reduced Steel Sheets. Journal of Structural Engineering, ASCE, 2011. 138(4): p. 459-467. 